\title{
University of Montana
}

ScholarWorks at University of Montana

$12-2018$

\section{METAL CONTAMINATION AND FOOD WEB CHANGES ALTER EXPOSURE TO UPPER TROPHIC LEVELS IN UPPER BLACKFOOT RIVER BASIN STREAMS, MONTANA}

Jack E. Landers

University of Montana, jack.landers@umontana.edu

Sean Sullivan

Rhithron Associates Inc.

Lisa Eby

University of Montana - Missoula

Andrew C. Wilcox

University of Montana - Missoula

Heiko Langner

Follow this and additional works at: https://scholarworks.umt.edu/geosci_pubs

Part of the Earth Sciences Commons

\section{Recommended Citation}

Landers, Jack E.; Sullivan, Sean; Eby, Lisa; Wilcox, Andrew C.; and Langner, Heiko, "METAL CONTAMINATION AND FOOD WEB CHANGES ALTER EXPOSURE TO UPPER TROPHIC LEVELS IN UPPER BLACKFOOT RIVER BASIN STREAMS, MONTANA" (2018). Geosciences Faculty Publications. 47.

https://scholarworks.umt.edu/geosci_pubs/47

This Article is brought to you for free and open access by the Geosciences at ScholarWorks at University of Montana. It has been accepted for inclusion in Geosciences Faculty Publications by an authorized administrator of ScholarWorks at University of Montana. For more information, please contact scholarworks@mso.umt.edu. 


\title{
METAL CONTAMINATION AND FOOD WEB CHANGES ALTER
}

\section{EXPOSURE TO UPPER TROPHIC LEVELS}

\section{IN UPPER BLACKFOOT RIVER BASIN STREAMS, MONTANA}

Jack Landers ${ }^{1}$, Sean Sullivan ${ }^{2}$, Lisa Eby ${ }^{3}$, Andrew C. Wilcox ${ }^{4}$, Heiko Langner ${ }^{4,5}$

1. Environmental Studies Program, University of Montana, Missoula, MT

2. Rhithron Associates Inc., Missoula, MT

3. Dept. of Ecosystem and Conservation Sciences, University of Montana, Missoula, MT

4. Dept. of Geosciences, University of Montana, Missoula, MT

5. King Abdullah University of Science and Technology, Thuwal, Saudi Arabia

E-mail addresses: ${ }^{1}$ jacklanders1@gmail.com ${ }^{2}$ ssullivan@rhithron.com ${ }^{3}$ lisa.eby@umontana.edu

4andrew.wilcox@umontana.edu, 5heiko.langner@kaust.edu.sa

\begin{abstract}
:
Reduced invertebrate abundance and diversity are common responses to metals contamination in miningimpacted streams. The resulting changes in community composition may have implications for metals accumulation and transfer through the food web. We investigated how changes in invertebrate community composition (abundance, species richness, and food web complexity) influence metals bioaccumulation and exposure risk to upper trophic levels along a contamination gradient in the upper Blackfoot River Basin, Montana. Invertebrate species richness exhibited the strongest decline with increasing sediment metals concentrations, driven by the loss of metals-sensitive taxa. These changes in invertebrate community composition resulted in a decline in the proportion of invertebrates in the scraper functional feeding group, likely influencing dietary metals exposure to the invertebrate community. Additionally, invertebrates with a strong propensity-to-drift increased with sediment contamination, potentially facilitating metals transfer to fish and higher trophic levels through predation. Using invertebrate exposure values (invertebrate abundance $x$ metals concentrations), we found that moderately contaminated sites in our study area produced both the highest invertebrate exposure values and the highest fish tissue metals concentrations. Considering both changes in invertebrate community composition and metal concentrations is an important step towards understanding and evaluating potential toxic effects to upper trophic levels in mining-impacted streams.
\end{abstract}

Keywords: Pollution, macroinvertebrate community structure, aquatic communities, acid mine drainage, Upper Blackfoot Mining Complex

This is a post-peer-review, pre-copyedit version of an article published in Hydrobiologia. The final authenticated version is available online at: $\underline{h t t p: / / d x . d o i . o r g / 10.1007 / s 10750-018-3857-8 ~}$

\section{Acknowledgments}

This research was funded by the US Environmental Protection Agency and the US Forest Service. We thank Nick Hehemann, Robert Livesay, Doug Brinkerhoff, and Matt Corsi for field data collection and Johnnie Moore for guidance. We also thank Will Clements and anonymous reviewers for comments that greatly improved the manuscript.

Page 1 of 34 


\section{Introduction}

Heavy metals can have profound impacts on aquatic communities across food webs, including reduced diversity and abundance of aquatic biota. The predictable response of aquatic invertebrate communities to metals contamination has formed the foundation for studies investigating speciesspecific and community-level impacts of metals contamination (Poulton et al., 1995; Beltman et al., 1999; Clements et al., 2000; Monna et al., 2011; Hogsden \& Harding, 2012). Studies of food webs, bioaccumulation, and trophic transfer of contaminants have also been applied to investigate functional changes in aquatic ecosystems in response to mining contamination (Besser et al., 2001; Carlisle, 2001; Campbell et al., 2003). Relatively few studies have linked these principles to evaluate how changes in community composition and biomass influence bioaccumulation and trophic transfer of contaminants to upper trophic levels and terrestrial consumers (Currie et al., 1997; Quinn et al., 2003; Kraus et al., 2014). Exposure pathways of metals accumulating in organisms are influenced by species-specific feeding mode, behavior, and life history traits (Croteau et al., 2005; Farag et al., 2007), which may have important implications for the transfer of metals through aquatic food webs as community composition changes in response to acid mine drainage.

Aquatic organisms are exposed to metals from numerous pathways, including dissolved metals in water, contaminated food sources, and direct contact with contaminated sediment. Several studies have documented strong correlations among metals concentrations in sediment, water, and periphyton that are potential sources of exposure to aquatic organisms (Axtmann et al., 1997; Beltman et al., 1999; Farag et al., 2007; Mebane et al., 2015). However, these studies also found variation in correlations among environmental contamination levels and tissue concentrations, as life-history traits, trophic status, and metals tolerance influence bioaccumulation in aquatic organisms. In the present study, we evaluated metals concentrations in sediment as a correlate for direct exposure from dominant pathways for aquatic organisms and to characterize contamination status of our study sites.

Because diet is the primary route of exposure for some metals in organisms such as fish, metals transferred through predation can accumulate in upper trophic levels (Woodward et al., 1994). Invertebrate biomass represents a major source of metals that are bioavailable to upper trophic levels in aquatic (e.g., fish) and riparian food webs (e.g., spiders, bats, and birds) (Jezierska \& Witeska, 2006; Kraus et al., 2014). As total invertebrate abundance and biomass decline in contaminated streams, the total pool of metals in the biota declines and reduces the flux of contaminants through food webs (Kraus et al., 2014). Ultimately, exposure risk to upper trophic levels is determined by interactions among 
mechanisms that influence the accumulation of metals in the invertebrate community (e.g. aqueous exposure, diet, metals tolerance and regulation) and food web complexity that influence the transfer of metals to upper trophic levels.

Multiple mechanisms may be responsible for and influence interactions among changes in community composition, metals accumulation in invertebrate communities, and metals transfer to upper trophic levels in mining-impacted streams. For example, changes in invertebrate community composition may result in a shift in the dominant functional feeding group and dietary exposure pathway of metals influencing aquatic invertebrate metals concentrations (Clements et al., 2000). Exposure pathways of metals to invertebrates include food sources or environmental exposure and numerous studies have observed elevated metals concentrations in periphyton and scraper functional feeding groups (Farag et al., 1998; Besser et al., 2001). Additionally, changes in composition may alter community characteristics, specifically invertebrate abundance, species diversity, number of trophic linkages, or densities of drifting invertebrates that facilitate trophic transfer of metals to fish. An increase in the abundance of species with a higher propensity-to-drift may increase the transfer of metals to fish via predation, as drifting invertebrates are the primary source of food for trout in mountain streams (Allan, 1981; Newman, 1987; Nakano et al., 1992). As a result, the pool of bioavailable metals and ultimate exposure risk to upper trophic levels in aquatic food webs may be strongly influenced by both exposure pathways of metals entering the aquatic food web and food web complexity. Evaluating how community composition changes across a metal contamination gradient and its effect on exposure pathways of metals in aquatic food webs may help refine our understanding of exposure risk to upper trophic levels in mining-impacted streams.

The goal of this study was to investigate how changes in community composition influence bioaccumulation, trophic transfer of heavy metals, and exposure risk to upper trophic levels along a contamination gradient in acid mine drainage-affected streams of the upper Blackfoot River Basin, Montana, USA. We hypothesized that moderately contaminated sites represent the greatest exposure risk of metals toxicity to upper trophic levels. This is because we expect that moderately contaminated sites, compared to those that are highly contaminated, support higher densities of invertebrates and more complex food webs that facilitate bioaccumulation and increase the flux of contaminants and trophic transfer of metals. To evaluate this hypothesis we examined whether invertebrate community characteristics (e.g., metrics of density, species richness, and food web complexity) decreased as contamination increased and whether these changes consequently (1) altered functional feeding group 
composition and increased environmental metals exposure from a shift in the dominant invertebrate food source; (2) altered the potential flux of metals through an invertebrate community's propensity-todrift, representing a connection to upper trophic levels; and/or (3) increased exposure values to upper trophic levels along the contamination gradient.

\section{Materials and Methods}

\section{Study Area}

We surveyed streams in the upper Blackfoot River Basin, Montana, to assess mining-related metals contamination and aquatic community impacts. The headwaters of the Blackfoot River are designated as a Superfund site known as the Upper Blackfoot Mining Complex to remediate the effects of acid mine drainage associated with abandoned mines, the largest of which was the Mike Horse Mine, and of the 1975 Mike Horse tailings dam failure that deposited over 150,000 $\mathrm{m}^{3}$ of toxic mine tailings and sediment downstream into the Blackfoot River (Montana Department of Environmental Quality, 2016). Recent remediation work at the Upper Blackfoot Mining Complex has included construction of a water treatment plant (in 2009), removal of the tailings dam (completed in 2015), and transfer of several hundred thousand cubic meters of contaminated tailings formerly impounded by the dam to an off-channel repository (Montana Department of Environmental Quality, 2016).

After the 1975 dam failure, drastic declines in fish and macroinvertebrate abundance were documented downstream of the tailings dam in 1975 and 1976 (Montana Fish Wildlife and Parks, 1997). Subsequent studies have documented persistent water quality and habitat impairments in the Blackfoot River and mining-impacted tributaries, including several lacking fish populations and having severely reduced invertebrate abundances (Moore et al., 1991; Nagorski et al., 2002a; Schmitz et al., 2010; Vandeberg et al., 2011). Two natural wetland complexes along the Blackfoot River downstream of the Mike Horse Dam limited downstream transport of mine tailings, but water quality impairments extended downstream of the wetlands (Moore et al., 1991; Vandeberg et al., 2011). Moore et al. (1991) detected elevated cadmium concentrations in fish and invertebrates $75 \mathrm{~km}$ downstream from the Upper Blackfoot Mining Complex, indicating that contaminants can be highly mobile and are prone to bioaccumulation in this system. Similarly, Nagorski et al. (2002) documented elevated metal concentrations in sediments extending $100 \mathrm{~km}$ downstream of the Upper Blackfoot Mining Complex, and that sediment-metal concentrations were similar in 1989, 1995, and 1998. 
To achieve our study goal, we selected sampling locations throughout the headwaters of the Blackfoot River (Figure 1) to reflect the range of contamination in the ecosystem. Sampling sites were 80 to $200 \mathrm{~m}$ long. Of our contaminated sites, six were located on the mainstem Blackfoot River downstream of the Mike Horse Dam (B0, B1, B2, B3, B4, B5) and one on a tributary site (Shave Gulch $\mathrm{SG}$ ). The mainstem sites include one location (B0) above the water treatment facility, two sites (B1 and B2) between the treatment facility and the first wetlands complex, one site (B3) between the two wetlands along the Blackfoot River, and two downstream sites (B4 and B5). Reference sites included eight tributary sites (Anaconda Creek - AC, Beartrap Creek - BC, Cadotte Creek - CD, Copper Creek - CuC, Meadow Creek - MC, Snowbank Creek - SC, Willow Creek - WC1 \& WC2) (Figure 1), some of which were selected to provide reference sites with similar drainage areas to mainstem contaminated sites. The term "reference site" in this context was used to describe sites that have known low impacts from historic mining. Small, often unmapped mines were widespread throughout the watershed, however, and have likely affected our reference sites together with other land uses. Exposure to impacts from unmapped mines and other land uses, as well as naturally occurring sources of heavy metals, may influence aquatic communities in all streams in the study area.

\section{Field sampling and laboratory analyses}

We collected sediment and water samples for metals analysis two to four times in 2009, between May and July depending on the site, and four times in 2010, between May and October (sampling at site W2 occurred 3 times) to evaluate metals exposure to aquatic organisms. Following methods in Shelton \& Capel (1994) and Moore \& Langner (2012), sediment samples were collected with plastic spoons and wet-sieved to include only the fine-grain fraction ( $<63 \mu \mathrm{m})$ from the upper $1-3 \mathrm{~cm}$ of stream substrate, representing the most biologically active and mobile sediments. The resulting sample amounts to $\sim 3-20 \mathrm{~g}$, depending on the fines content of the original sediment sample. Wet samples were stored on ice for up to $24 \mathrm{~h}$, before being centrifuged, decanted and dried at $60^{\circ} \mathrm{C}$. Water samples were collected in 1-liter acid-washed bottles and stored on ice for transport to the laboratory and further processing which occurred within $24 \mathrm{~h}$. Subsamples were filtered using $0.45 \mu \mathrm{m}$ syringe filters and acidified with $0.1 \mathrm{~mL}$ trace metal grade concentrated $\mathrm{HNO}_{3}$ in $100 \mathrm{~mL}$ water. Metals/metalloid analyses of sediment were conducted using $0.4 \mathrm{~g}$ subsamples of the dried and homogenized fine sediments according to EPA Methods 3050B (aqua regia digest) and 200.7 (ICP-OES 
analysis). Field blanks and duplicates were obtained during each sampling event according to USEPA guidelines (U.S. Environmental Protection Agency, 1991). For the analysis of sediment and water, we focused on six metals/metalloids associated with mining in the study area (Moore et al., 1991) that have been shown to be toxic at elevated levels to aquatic organisms: arsenic, cadmium, chromium, copper, lead, and zinc (U.S. Environmental Protection Agency, 2007, 2016).

We collected macroinvertebrate samples using a $0.093 \mathrm{~m}^{2}$ Surber sampler for community composition from several locations within three distinct riffles at each site. We disturbed substrate within the Surber sampler's frame and scraped the substrate free of organisms and detritus and into the Surber net; the remaining sample was decanted of excess water and preserved with a $95 \%$ ethyl alcohol solution. In a laboratory, samples were sub-sampled to a minimum of 500 randomly selected organisms using a 30 grid Caton tray (Caton, 1991) and random-number generator to avoid bias in selecting the subsample (e.g., Feldman et al., 2012). Percent substrate sub-sampled was recorded in order to estimate invertebrate density. All organisms were identified to the lowest practical taxonomic level, consistent with Montana Department of Environmental Quality protocols (Feldman et al., 2012). Ten percent of the community composition samples were re-identified by a second taxonomist for taxonomic quality control.

A separate invertebrate sample was collected at each site for whole-body metals analysis. We analyzed concentrations of arsenic, copper, cadmium, and zinc in the biota, as these are metals of primary concern identified in previous studies in the study area (Moore et al., 1991) and are suitable for addressing our study questions. Samples for metals analysis were collected using a d-frame kick net and a sampling period of one minute, or until sufficient mass of the target taxa were collected. Invertebrates targeted for metals analyses in 2009 were chosen due to the prevalence of these taxa in previous studies in the upper Blackfoot River (Moore et al., 1991), and their relative ease of field identification. The six target taxa included Hydropsyche spp., Arctopsyche grandis (Banks, 1900), Limnephilus spp., Brachycentrus spp., Claassenia sabulosa (Banks,1900), and Hesperoperla pacifica (Banks,1900). Not all target species were present at all sampling stations, however, constraining comparison among sites. For the 2010 sampling period, we modified our sampling scheme to include ubiquitous taxa in our study area, which included Rhyacophila sp., Drunella coloradensis (Dodds, 1923), Arctopsyche grandis, Brachycentrus spp., and Claassenia sabulosa. A total of 150 individuals collected in 2009 and 2010 were analyzed for metals concentrations. 
A minimum of ten individuals or $50 \mathrm{mg}$ dry mass per taxon were combined to meet laboratory analytical requirements. Specimens were hand-picked from collection basins in the field using plastic forceps and transferred to acid-cleaned scintillation vials for metals analysis, and no preservatives or water were added to the sample containers to avoid specimen depuration. Additional samples were also returned to the lab for verification of the taxon. Each composite was digested and analyzed on a PerkinElmer Elan DRCe ICP-Mass Spectrometer, following a standard procedure for biological tissues (Langner et al., 2012).

Fish populations were sampled with a two-pass depletion method using a backpack electrofisher in $200 \mathrm{~m}$ block-netted reaches at each site. From sites where fish were present (MC, SG, AC, B1, B2, B3, B4, B5), 77 fish were sacrificed for metals analysis of livers. The target fish species for metals analysis was non-native brook trout [Salvelinus fontinalis (Mitchill, 1814)] which are relatively abundant in this system and were present in 6 of the 8 fish-bearing reaches. Westslope cutthroat trout [Oncorhynchus clarkii lewisi (Girard, 1856)] were collected from sites MC and AC, where brook trout were absent. Fish were euthanized with an overdose ( $2 \mathrm{~g} / \mathrm{L}$ ) of MS-222 (tricaine methanesulfonate). Livers were removed immediately and frozen on dry ice before being stored at $-80^{\circ} \mathrm{C}$ until analysis. Ten analytical samples were collected from each site; we composited several livers when individual specimens did not provide sufficient sample mass for analysis. Liver samples (about $1 \mathrm{~g}$ ) were digested and analyzed with ICP-MS as described in Langner et al. (2012).

We quantified stream physical characteristics to evaluate the influence of habitat conditions, in addition to metals contamination, in structuring aquatic communities. The variables used in our analyses included: water temperature, electrical conductivity, $\mathrm{pH}$, alkalinity, total suspended solids, drainage area, and substrate size. Temperature and electrical conductivity were measured in the field with a Mettler Toledo Model MC126 portable conductivity meter/IP67 conductivity cell. In the field, we measured $\mathrm{pH}$ with an ORION Model 265A portable $\mathrm{pH}$ meter and gel $\mathrm{pH}$ probe after calibrating the $\mathrm{pH}$ meter using two buffers bracketing the field $\mathrm{pH}$ readings. We measured alkalinity in the field using a Hach model AL-DT alkalinity kit with manufacturer-prescribed procedure. Total suspended solids were quantified gravimetrically by filtering $1 \mathrm{~L}$ stream water samples through pre-weighed glass fiber filters (Clesceri et al., 1998). Wolman pebble counts of 100 clasts each were conducted at three transects in each reach to quantify substrate size (Wolman, 1954). 


\section{Data Analyses}

Both sediment and water samples were collected and analyzed at each sampling event, but we included only concentrations in sediment to estimate local levels of metals/metalloid toxicity. Concentrations in fine-grain surface sediment have been shown to correlate well with exposure levels in aquatic organisms (Beltman et al., 1999; Farag et al., 2007; Luoma et al., 2008; Mebane et al., 2015), to remain elevated in mining-impacted streams for decades to centuries after the cessation of mining activities (Monna et al., 2011), and to have relatively high reproducibility of sampling and analysis (Moore \& Langner, 2012). Dissolved metals concentrations were not used in the analysis presented here as their levels were low, often below detectable levels, and varied widely due to seasonal and weatherdependent shifts in stream water origin, consistent with other studies (e.g., Axtmann et al., 1997, Monna et al., 2011). For reference purposes, however, dissolved metals concentrations from our water samples are presented in Supplemental Information (Supplemental data - Water_quality). Stream water that primarily consists of spring snowmelt is naturally low in dissolved constituents while late-summer stream flow is dominated by groundwater with potentially much higher dissolved metals concentrations due to extended contact with the local geology and mine tailings (August et al., 2002; Song et al., 2015). We used Cumulative Sediment Criterion Units (CSCU) to account for additive toxicity effects of multiple metals in sediment to aquatic biota, similar to the approach used to quantify additive toxicity effects of metals in water (Clements et al., 2000). Our CSCU values characterize persistent contamination status and serve as a correlate for the pool of metals that are potentially bioavailable in other compartments, such as water and periphyton, but CSCU does not measure direct toxicity to aquatic organisms. The sum of the ratio of observed metals concentrations in sediment to the consensus-based Probable Effect Concentration (PEC) for individual metals in sediment reported by Macdonald et al. (2000) is used to calculate the CSCU:

$$
\mathrm{CSCU}=\sum \frac{\text { Metal }_{i}}{P E C_{i}}
$$

where $\mathrm{Metal}_{i}$ is the observed metal concentration for the $i^{\text {th }}$ metal and $P E C_{i}$ is the probable effect concentration for the $i^{\text {th }}$ metal. The consensus-based PEC's were developed from 17 field studies conducted throughout the United States, including the Clark Fork River, Montana (U.S. Fish and Wildlife Service, 1993; MacDonald et al., 2000), which neighbors the Blackfoot River Basin. Sediment metals concentrations greater than the PEC are likely to cause toxicity effects to aquatic biota, and CSCU values greater than one indicate potential toxic effects to aquatic biota from additive contributions of multiple 
metals. We used arsenic, cadmium, chromium, copper, lead, and zinc concentrations in sediment to calculate the CSCU for each site. To account for intraannual variability in sediment metals concentrations over the sampling period and provide a representative characterization of each site, the median CSCU for each year at individual sites was used.

We analyzed the standardized Surber sample data collected in 2009 and 2010 for our community composition metrics to understand how community characteristics change along the contamination gradient. Community characteristics include aquatic invertebrate density, species richness, and food web complexity. Food web complexity was calculated by multiplying the number of species in one trophic level by the number of species in the next highest trophic level and summed for all trophic groups present (Bersier et al., 2002). We identified three trophic levels in this study according to general feeding traits and trophic position, which included 1) herbivorous invertebrates, 2) predatory invertebrates, and 3) trout.

We evaluated whether variation in our community characteristics could be associated with water quality variables ( $\mathrm{pH}$ and water temperature), physical characteristics (drainage area and substrate size), and/or sediment contamination using multiple linear regression models. Model assumptions were checked using residual plots, variable inflation factors, and normal quantile plots to avoid collinearity among explanatory variables and ensure that an appropriate model was selected. We standardized our variables describing water quality and physical characteristics and applied a natural-log transformation to median CSCU data to provide a linear relationship between community characteristics metrics and sediment contamination levels and satisfy model assumptions. We identified the best fit model using Akaike's Information Criterion (AIC) model selection (Akaike, 1973). All statistical analyses were computed using R statistical software (R Core Team 2015).

We used invertebrate functional feeding groups (hereafter, FFG) and propensity-to-drift to investigate how changes in community composition influence metals exposure to the invertebrate community and to upper trophic levels. We examined changes in FFG by assigning group membership using specific feeding traits for lotic aquatic invertebrates in North America (Poff et al., 2006) (Table 5). Functional feeding groups evaluated include collector-filterer, collector-gatherer, predator, scraper/grazer, and shredder. Changes in the proportion of scraper and collector-filterer groups are the primary focus of this study as the dominant food resource (autochthonous versus allochthonous) may vary between these groups with potentially important differences in metals exposure (Farag et al., 1998; 
Besser et al., 2001). The proportion of FFGs for each invertebrate community was calculated by dividing the density of each FFG by the total density of invertebrates at each sampling reach.

In addition to changes in invertebrate FFG, we examined how fish prey availability or aquatic invertebrate drift varied across sediment contaminant concentrations to evaluate potential metals exposure in fish. We ranked invertebrate taxa into categories of weak, medium, and strong propensityto-drift (Ward \& Kondratieff, 1992; Rader, 1997; Poff et al., 2006). The propensity-to-drift rankings reflect a species' relative availability to fish and were used to quantify food availability and trophic transfer of metals from invertebrates to fish at each site.

We used simple linear regression models to evaluate relationships between the proportions of the community in different FFG or drift category and sediment contamination (CSCU), as well as associations of invertebrate metals concentrations and sediment contamination. We focused on arsenic, cadmium, copper, and zinc in invertebrates and fish for these analyses, because as noted above these are the primary metals of concern in aquatic organisms in the upper Blackfoot River (Moore et al., 1991). We analyzed community composition data separately for each year, whereas metals analyses in biota were combined for both years due to the consistency in habitat and community composition metrics among years, as well as the small amount of metals data available. Model assumptions were checked using the methods described above for multiple linear regression models. We applied a natural log transformation to the median CSCU data to achieve a linear relationship between our FFG and sediment contamination levels and satisfy model assumptions.

In order to answer our primary research question of how changes in community composition influence metals exposure risk to upper trophic levels, we examined the relationship between invertebrate abundance and organism metals concentrations along the contamination gradient in the upper Blackfoot River. We calculated invertebrate exposure values to provide a quantitative estimate of the flux of contaminants potentially transported by the invertebrate community. These values were calculated by multiplying the metals concentrations of each invertebrate collected for metals analyses by the density of that species at the corresponding sampling reach quantified from the standardized Surber samples. Exposure values for arsenic, cadmium, copper, and zinc were used to evaluate the potential transport of these metals up the food chain to fish by the invertebrate biomass. Finally, we plotted fish metals concentrations to examine whether fish contaminant concentrations had a similar pattern to invertebrate exposure values. 
We used invertebrate exposure values as an indicator of exposure risk to upper trophic levels in this study by estimating the total metals burden in the invertebrate community as a product of invertebrate density and tissue metals concentrations. Similar methods have been used to estimate the quantity of metals transported by invertebrates in aquatic systems using invertebrate biomass (Menzie, 1980; Kraus et al., 2014). Invertebrate exposure values are an estimate of the metals that are available to fish through predation, as well as a characterization of contamination at each site. High exposure values reflect higher invertebrate abundance that may indicate conditions that promote complex food webs and the presence of upper trophic levels. Sub-lethal metals concentrations coinciding with complex food webs and high invertebrate abundance may have important community level impacts as metals accumulate in aquatic biota through biological mechanisms. Exposure values should be interpreted with caution, however, because they may not be representative of the food actually consumed by fish due to the lack of direct observations of fish diets in this study.

\section{$\underline{\text { Results }}$}

Metals concentrations measured in CSCU were far higher at contaminated sites along the mainstem Blackfoot River (average $=42$ ) than at reference sites (average $=3$ ) (range $=1-105$ for all sites; Table 1, Figure 2a). Along mainstem Blackfoot River sites, CSCU in sediment declined substantially downstream of the Mike Horse tailings dam, with little variation between years (Figure 2b).

The CSCU accounts for additive toxicity effects of multiple metals in fine sediment at each site, but may vary in the relative contributions from each metal (Table 1). When only reference sites are considered, arsenic, zinc, and copper accounted for the largest percent of the CSCU values. Among impact sites only, all metals were elevated, including arsenic, but lead, zinc, and copper represented the largest portion of the CSCU values. As a result, it is evident that arsenic, zinc, and copper are ubiquitous contaminants in this study area that can have important toxicity effects for aquatic biota.

Aquatic invertebrate density, species richness, and food web complexity all declined significantly with increasing sediment metals contamination in both 2009 and 2010 (Adj. $R^{2}=0.55-0.76, p<0.01$, Figure 3). Sediment contamination (median CSCU) explained the most variation in all three community metrics in both years (Table 2). In all multiple regression models, except for the 2009 Density model, percent sand and finer $(<2 \mathrm{~mm})$ in the substrate and sediment contamination were both important predictors of invertebrate community characteristics. In general, invertebrate species richness and food 
web complexity showed a stronger relationship with the explanatory variables than invertebrate density, with greater than $65 \%$ of the variation explained by the regression models (Table 3 ).

Metals concentrations in sediment also influenced invertebrate community functional groups. The proportion of invertebrate scrapers showed a negative relationship with sediment contamination in both 2009 and 2010 but with considerable variation across the range of sediment contamination levels $\left(p<0.05, R^{2}=0.2,0.38\right)$. The proportion of collector-filterers exhibited a positive relationship with sediment contamination in $2009\left(p<0.05, R^{2}=0.15\right)$ and no apparent relationship in $2010\left(p>0.1, R^{2}=\right.$ 0) (Figure 4a). The proportion of invertebrates with a strong propensity-to-drift generally increased with sediment contamination, with a corresponding decline in the proportion of invertebrates with a weak propensity-to-drift $\left(p<0.05, R^{2}=0.18-0.47\right)$ (Figure $\left.5 a\right)$. The proportion of invertebrates with a medium propensity-to-drift did not change with increasing sediment contamination.

Across most metals examined, sediment contamination was a poor predictor of metals concentrations in invertebrates among our study sites (Figures $4 \mathrm{~b}$ and $5 \mathrm{~b}$ ). Metals concentrations of invertebrates grouped by drift category and by FFG (Table 5) varied considerably across the range of sediment contamination levels with only $2-18 \%$ of the observed variation explained by regression models using CSCU as the explanatory variable (Table 4). Copper concentrations in invertebrates were positively associated with sediment contamination $\left(R^{2}=0.3-0.4\right)$. Additionally, copper and zinc concentrations in invertebrates showed a significant relationship with sediment contamination across both years and all FFG and drift categories $(p<0.01$ ) (Table 4). Numerous samples with high invertebrate metals concentrations at moderately contaminated sites and low invertebrate metals concentrations at highly contaminated sites confound the relationship between invertebrate metals concentrations and sediment contamination. With the exception of copper in the drift category models, the regression line intercepts and slopes are not significantly different (ANCOVA $p>0.05$ ), indicating that invertebrates in both drift categories and functional feeding groups accumulate metals similarly and do not show significantly different magnitudes of metals concentrations among groups.

Exposure values (invertebrate taxon density $\mathrm{x}$ invertebrate taxon metals concentrations) were used to represent the potential flux of contaminants transported by the invertebrate community to upper trophic levels through predation. The plots of exposure values versus sediment metals concentrations exhibit a similar pattern across cadmium, copper, and zinc analyzed in invertebrates (Figure 6). With two notable exceptions, the highest exposure values were observed at moderately contaminated sites with sediment CSCU values of 65 . Two samples for arsenic and cadmium exhibit very 
high exposure values coinciding with low sediment contamination levels. In addition, arsenic did not show a strong relationship with sediment contamination. All four plots in Figure 6 show considerable variation across the range of CSCU values, suggesting that metals bioavailable to fish may be better predicted by invertebrate community structure rather than environmental contamination levels alone.

Fish were observed at most sites, with the exceptions of B0 (both 2009 and 2010), BC and B1 (2009), and B3 (2010). The highest metals concentrations in fish that were sampled occurred at moderately contaminated sites in our study area with a CSCU value of 65 (Figure 7). Arsenic, cadmium, and copper showed higher concentrations in fish tissue at these sites with zinc showing considerable variation across all sites. Fish that were sampled in 2010 generally had higher tissue metals concentrations and higher invertebrate densities at the low and moderately contaminated sites, likely due to the location of sites sampled in each year. Sites with the highest metals concentrations in fish were also the sites with the highest invertebrate exposure values (CSCU $=65)$.

\section{Discussion}

This study provides evidence that species interactions and biological mechanisms play an important role in predicting heavy metals exposure to upper trophic levels in aquatic food webs. Invertebrate abundance, species richness, and food web complexity all declined significantly with increasing sediment contamination in our study. Invertebrate species richness exhibited the strongest response to sediment contamination, reflecting elimination of metals-sensitive taxa and predominance of metals-tolerant taxa in highly contaminated sites. This loss in the number of taxa had significant effects on invertebrate functional groups, with a decline in the proportion of invertebrates in the scraper FFG and an increase in the proportion of invertebrates with a strong propensity-to-drift. Changes in invertebrate functional groups may help explain our observation of the highest invertebrate exposure values at moderately contaminated sites. In addition, the highest metals concentrations in fish coincided with sites that had the highest invertebrate exposure values, suggesting that these conditions produced the greatest flux of contaminants from the invertebrate community to upper trophic levels. Our results indicate that the greatest exposure risk to upper trophic levels occurs at moderately contaminated sites where conditions promote the accumulation of metals in the aquatic community while also supporting complex food webs that facilitate the transfer of metals to upper trophic levels.

Metals bound to fine sediment provide a proxy for contaminant exposure to the invertebrate community through common pathways (i.e., diet). Invertebrate community characteristics declined 
significantly with increasing sediment metals concentrations, suggesting that CSCU is an appropriate surrogate for evaluating community-level impacts of metals toxicity, even if the primary exposure pathway to aquatic organisms is aqueous exposure or diet. However, the lack of data for all exposure pathways at our sites precludes empirical analysis of correlations among various exposure pathways.

Our results highlight the persistent effects of historic mining and the Mike Horse tailings dam breach on metals contamination of aquatic sediments in this region, as well as the spatial variability in metals concentrations both downstream along the Blackfoot River and among tributaries. The decline in invertebrate abundance and species richness with increasing metals contamination in the upper Blackfoot River Basin streams is consistent with other studies evaluating the impacts of abandoned mines on aquatic environments (Poulton et al., 1995; Beltman et al., 1999; Clements et al., 2000). The strongest response observed in the invertebrate community to metals contamination at our sites was the decline in the number of invertebrate taxa. At more contaminated sites, there was a lower density and the invertebrate community was composed of primarily metals-tolerant taxa, similar to Beltman et al. (1999). These changes in invertebrate community composition likely drove the differences we observed in invertebrate metals exposure, as well as the transfer of metals to upper trophic levels.

The proportion of scrapers declined across sites with increasing sediment contamination, decreasing the contribution of autochthonous resources supporting the aquatic food web. Several studies have documented higher metal loads in periphyton resulting in higher metals concentrations in invertebrates in the scraper functional feeding group (Farag et al., 1998; Besser et al., 2001). The higher abundance of scrapers in moderately contaminated sites may therefore drive an overall increase in metals concentrations in the invertebrate community. Metals concentrations among FFG in our sites did not demonstrate significantly different concentrations among groups, potentially due to the importance of waterborne metals exposure or physical and chemical conditions in the upper Blackfoot River, such as $\mathrm{pH}$ and colloid formation, that influence metals accumulation in invertebrate food sources (Schemel et al., 2000; Farag et al., 2007). Cadmium and copper concentrations in several invertebrate scraper samples were higher than in collector-filterers at the same site (SG 2009, median CSCU = 7.2), which may help explain the higher concentrations in fish at these sites. Analysis of metals in invertebrate food sources could provide further insights into differences in metals accumulation among invertebrate functional feeding groups.

Trout tend to feed primarily on drifting invertebrates, representing an important source of metals exposure from the invertebrate community to fish (Allan, 1981; Newman, 1987; Nakano et al., 
1992). We observed an increase in the proportion of invertebrates with a strong propensity-to-drift with sediment contamination, potentially facilitating the transfer of metals to upper trophic levels in contaminated sites via predation. The relationship between sediment contamination levels and drifting invertebrates would be especially important if invertebrates with a strong propensity-to-drift exhibited higher metals concentrations than invertebrates with a weak propensity-to-drift. We did not observe a difference in metals concentrations between drift categories, however, possibly due to the similarities in habitat types and food sources exploited by taxa in each drift category. As a result, fish that feed primarily on drifting invertebrates are likely not exposed to higher metals concentrations than fish feeding primarily on more sedentary organisms. However, the observed increase in the proportion of invertebrates with a high propensity-to-drift in contaminated sites could reinforce the positive relationship between exposure values and fish metals concentrations by increasing food availability for trout, maintaining habitat suitability in contaminated sites despite metals toxicity, and facilitating metals transport to upper trophic levels.

This study highlights the linkages between invertebrate abundance and metals concentrations influencing contaminant transport to upper trophic levels (Currie et al., 1997; Kraus et al., 2014). Despite the strong evidence of hostile conditions for aquatic life in the contaminated sites we surveyed (CSCU > 1), metals exposure in upper trophic levels were reduced at these sites likely due to low invertebrate abundance and reduced food availability for predators. In the present study, invertebrate exposure values suggest that the greatest flux of contaminants could potentially occur at moderately contaminated sites. In addition, these sites contained a larger fish population, facilitating the transfer of metals through the food web. Similarly, Kraus et al. (2014) found that the greatest export of aquatic contaminants to riparian food webs occurred at sites with lower contamination levels due to the increased abundance of emergent insects.

The highest exposure values observed in this study occurred at moderately contaminated sites with a CSCU of 65 (Figure 6). Several of these high exposure values were observed at site B2, downstream of a water treatment plant that is intended to reduce the impacts of acid mine drainage. In addition, sites with low sediment contamination levels produced relatively high exposure values as invertebrate density was highest at these locations (Sites SC and AC, median CSCU = 2). Sediment CSCU values declined significantly in the mainstem Blackfoot River sites with minimal variation as the distance from the Mike Horse Dam increased (Figure 2b). In contrast, invertebrate exposure values exhibit considerably more variation with high exposure values at sites with moderate and low sediment 
contamination levels indicating that the potential transfer of metals from the invertebrate community is greatest at moderately contaminated sites where exposure values are driven by higher invertebrate density and metals bioaccumulation.

Arsenic plays a dominant role in reduced growth and survival in fish feeding on a contaminated diet in mining impacted systems and we observed arsenic concentrations in invertebrates that exceed toxic thresholds described in previous studies (Table 5) (Hansen et al., 2009; Erickson et al., 2010, 2011). Arsenic patterns in study area streams are complex as a result of strong partitioning between the solid and dissolved phase and large local variability in arsenic sources (Nagorski et al., 2002b). Despite the lack of a relationship between exposure values and sediment contamination, invertebrate arsenic concentrations occurred at levels that likely have detrimental impacts to aquatic organisms at all sites (Table 5) (Hansen et al., 2009; Erickson et al., 2010, 2011). Arsenic exposure values therefore may not adequately represent arsenic toxicity to aquatic organisms throughout the mining-impacted portions of our study area.

Limitations in our data precluded direct analysis of the relationship between fish diet and fishtissue metals concentrations. High invertebrate exposure values and high metals concentrations in fish tissue at moderately contaminated sites nevertheless indicate potentially important interactions between physical and chemical conditions and metals exposure to aquatic organisms that influence metals accumulation in upper trophic levels. As a result, whether direct exposure via dissolved metals or indirect exposure through diet is the dominant route of metals uptake in fish in our study, we consider invertebrate exposure values to be a reasonable alternative to measuring a suite of complex factors that ultimately dictate exposure risk to upper trophic levels in contaminated streams. The use of invertebrate biomass as a measure of metals flux via predation and analysis of fish diet to determine the relative contribution of various taxa to fish tissue metals concentrations could refine this approach for evaluating exposure risk to upper trophic levels.

\section{Conclusion}

Species interactions, food web complexity, and community composition can affect the biological movements of metals, in addition to the toxic effects from direct exposure to contaminants in water and sediment. We identified several changes in community composition with consequences for bioaccumulation and trophic transfer of metals, including a shift in invertebrate exposure pathways, a decline in invertebrate abundance and species richness, and ultimate metals accumulation in upper 
trophic levels. Higher densities of invertebrates and a greater proportion of invertebrates with a strong propensity-to-drift may be partially responsible for the elevated metals concentrations in fish tissue at moderately contaminated sites. Our results emphasize the necessity of evaluating community composition response, in addition to environmental contamination levels, when evaluating and managing exposure risk to fish and other upper trophic level species.

The results of this study and similar efforts to investigate the biological movement of metals in aquatic food webs (Currie et al., 1997; Quinn et al., 2003; Kraus et al., 2014) have implications for assessing exposure risk in acid mine drainage-impacted streams. Metal contamination from abandoned mines is a persistent problem worldwide, with approximately 46,000 identified abandoned mine sites in the United States (Bureau of Land Management, 2014). Due to the significant funding and resources required to remediate mining impacted aquatic systems, moderate contamination levels will likely persist at many sites with significant effects on aquatic communities. Understanding the relationship between environmental contamination and biological mechanisms of metals transfer through the food web may elucidate exposure risk in areas where contaminants are bioavailable but in relatively low to moderate environmental concentrations.

\section{Data availability statement}

All data generated or analyzed during this study are included in this published article or are available at the University of Montana ScholarWorks [https://scholarworks.umt.edu/geosci_data/2/] [Supplemental data files: Site_descriptions.csv, Site_map.pdf, Water_quality.csv, Fine_sediment_metals.csv, Fish_metals.csv, Fish_population.csv, Invertebrate_community_composition.csv, Invertebrate_metals.csv] 


\section{$\underline{\text { References }}$}

Akaike, H., 1973. Information theory as an extension of the maximum likelihood principle In Petrov, B., \& F. Csaki (eds), Second international symposium on information theory. Akaemiai Kiado, Budapest: 267281.

Allan, D. J., 1981. Determinants of diet of brook trout (Salvelinus fontinalis) in a mountain stream. Canadian Journal of Fisheries and Aquatic Sciences 38: 184-192.

August, E. E., D. M. McKnight, D. C. Hrncir, \& K. S. Garhart, 2002. Seasonal variability of metals transport through a wetland impacted by mine drainage in the Rocky Mountains. Environmental Science \& Technology 36: 3779-3786.

Axtmann, E. V., D. J. Cain, \& S. N. Luoma, 1997. Effect of tributary inflows on the distribution of trace metals in fine- grained bed sediments and benthic insects of the Clark Fork River, Montana.

Environmental Science and Technology 31: 750-758.

Beltman, D. J. B., W. H. Clements, J. Lipton, \& D. Cacela, 1999. Benthic invertebrate metals exposure, accumulation, and community-level effects downstream from a hard-rock mine site. Environmental Toxicology and Chemistry 18: 299-307.

Bersier, L. F., C. Banašek-Richter, \& M. F. Cattin, 2002. Quantitative descriptors of food-web matrices. Ecology 83: 2394-2407.

Besser, J. M., W. G. Brumbaugh, T. W. May, S. E. Church, \& B. a. Kimball, 2001. Bioavailability of metals in stream food webs and hazards to brook trout (Salvelinus fontinalis) in the upper Animas River watershed, Colorado. Archives of Environmental Contamination and Toxicology 40: 48-59.

Bureau of Land Management, 2014. Abandoned Mine Land Inventory Study for BLM-Managed Lands in California, Nevada, and Utah: Site and Feature Analysis. Denver, CO.

Campbell, P. G. C., A. Hontela, J. B. Rasmussen, A. Giguère, A. Gravel, L. Kraemer, J. Kovesces, A. Lacroix, H. Levesque, \& G. Sherwood, 2003. Differentiating between direct (physiological) and food-chain mediated (bioenergetic) effects on fish in metal-impacted lakes. Human and Ecological Risk Assessment: An International Journal 9: 847-866.

Carlisle, D. M., 2001. Trophic structure and function of stream food webs along a gradient of metal contamination (Doctoral dissertation). Colorado State University.

Caton, L. W., 1991. Improved subsampling methods for the EPA "Rapid Bioassessment" benthic protocols. Bulletin of the North American Benthological Society of America 8: 317-319.

Clements, W. H., D. M. Carlisle, J. M. Lazorchak, \& P. C. Johnson, 2000. Heavy metals structure benthic communities in Colorado mountain streams. Ecological Applications 10: 626-638.

Clesceri, L. S., A. E. Greenberg, \& A. D. Eaton (eds), 1998. Standard methods for the examination of water and wastewater. Page 2-59, $20^{\text {th }}$ edition. American Public Health Association, Washington, DC.

Croteau, M.-N., S. N. Luoma, \& a. R. Stewart, 2005. Trophic transfer of metals along freshwater food webs: Evidence of cadmium biomagnification in nature. Limnology and Oceanography 50: 1511-1519.

Currie, R. S., W. L. Fairchild, \& D. C. G. Muir, 1997. Remobilization and export of cadmium from lake 
sediments by emerging insects. Environmental Toxicology and Chemistry 16: 2333-2338.

Erickson, R. J., D. R. Mount, T. L. Highland, J. R. Hockett, \& C. T. Jenson, 2011. The relative importance of waterborne and dietborne arsenic exposure on survival and growth of juvenile rainbow trout. Aquatic Toxicology 104: 108-115.

Erickson, R. J., D. R. Mount, T. L. Highland, J. R. Hockett, E. N. Leonard, V. R. Mattson, T. D. Dawson, \& K. G. Lott, 2010. Effects of copper, cadmium, lead, and arsenic in a live diet on juvenile fish growth. Canadian Journal of Fisheries and Aquatic Sciences 67: 1816-1826.

Farag, A. M., D. A. Nimick, B. A. Kimball, S. E. Church, D. D. Harper, \& W. G. Brumbaugh, 2007. Concentrations of metals in water, sediment, biofilm, benthic macroinvertebrates, and fish in the Boulder River watershed, Montana, and the role of colloids in metal uptake. Archives of Environmental Contamination and Toxicology 52: 397-409.

Farag, A. M., D. F. Woodward, J. N. Goldstein, W. Brumbaugh, \& J. S. Meyer, 1998. Concentrations of metals associated with mining waste in sediments, biofilm, benthic macroinvertebrates, and fish from the Coeur d'Alene River basin, Idaho. Archives of Environmental Contamination and Toxicology 34: 119127.

Feldman, D., R. Bukantis, M. Mccarthy, \& D. Kron, 2012. Sample collection, sorting, taxonomic identification, and analysis of benthic macroinvertebrate communities standard operating procedure. Montana Department of Environmental Quality.

Hansen, J. A., J. Lipton, P. G. Welsh, D. Cacela, \& B. MacConnell, 2009. Reduced growth of rainbow trout (Oncorhynchus mykiss) fed a live invertebrate diet pre-exposed to metal-contaminated sediments. Environmental Toxicology and Chemistry 23: 1902-1911.

Hogsden, K. L., \& J. S. Harding, 2012. Consequences of acid mine drainage for the structure and function of benthic stream communities: a review. Freshwater Science 31: 108-120.

Jezierska, B., \& M. Witeska, 2006. The metal uptake and accumulation in fish living in polluted waters. Soil and Water Pollution Monitoring, Protection and Remediation 3: 107-114.

Kraus, J. M., T. S. Schmidt, D. M. Walters, R. B. Wanty, R. E. Zuellig, \& R. E. Wolf, 2014. Cross-ecosystem impacts of stream pollution reduce resource and contaminant flux to riparian food webs. Ecological Applications 24: 235-243.

Langner, H., E. Greene, R. Domenech, \& M. Staats, 2012. Mercury and other mining-related contaminants in ospreys along the Upper Clark Fork River, Montana, USA. Archives of Environmental Contamination and Toxicology 62: 681-695.

Luoma, S. N., J. N. Moore, A. Farag, T. H. Hilman, D. J. Cain, \& M. Hornberger, 2008. Mining Impacts on Fish in the Clark Fork river, Montana: A Field Ecotoxicology Case Study. Page 1071 in Di Giulio, R. T., \& D. E. Hinton (editors), Toxicology of Fishes. CRC Press, Boca Raton, FL.

MacDonald, D. D., C. G. Ingersoll, \& T. A. Berger, 2000. Development and evaluation of consensus-based sediment quality guidelines for freshwater ecosystems. Archives of Environmental Contamination and Toxicology 39: 20-31.

Mebane, C. A., R. J. Eakins, B. G. Fraser, \& W. J. Adams, 2015. Recovery of a mining-damaged stream 
ecosystem. Elementa: Science of the Anthropocene 3: 42.

Menzie, C. A., 1980. Potential significance of insects in the removal of contaminants from aquatic systems. Water, Air, and Soil Pollution 13: 473-479.

Monna, F., E. Camizuli, P. Revelli, C. Biville, C. Thomas, R. Losno, R. Scheifler, O. Bruguier, S. Baron, C. Chateau, A. Ploquin, \& P. Alibert, 2011. Wild brown trout affected by historical mining in the Cevennes National Park, France. Environmental Science and Technology 45: 6823-6830.

Montana Department of Environmental Quality, 2016. Record of Decision, Final Cleanup for the Upper Blackfoot Mining Complex State Superfund Facility. Lewis and Clark County.

Montana Fish Wildlife and Parks, 1997. Effects of the June, 1975 Mike Horse Mine Tailings Dam failure on water quality and aquatic resources of the Upper Blackfoot River, Montana. Helena, MT.

Moore, J. N., \& H. W. Langner, 2012. Can a river heal itself? Natural attenuation of metal contamination in river sediment. Environmental Science \& Technology 46: 2616-2623.

Moore, J. N., S. N. Luoma, \& D. Peters, 1991. Downstream effects of mine effluent on an intermontane riparian system. Canadian Journal of Fisheries and Aquatic Sciences 48: 222-232.

Nagorski, S. a., J. N. Moore, \& D. B. Smith, 2002a. Distribution of Metals in Water and Bed Sediment in a Mineral-Rich Watershed, Montana, USA. Mine Water and the Environment 21: 121-136.

Nagorski, S. A., J. N. Moore, \& D. B. Smith, 2002b. Distribution of metals in water and bed sediment in a mineral-rich watershed, Montana, USA. Mine Water and the Environment 21: 121-136.

Nakano, S., K. D. Fausch, T. Furukawa-Tanaka, K. Maekawa, \& H. Kawanabe, 1992. Resource utilization by bull char and cutthroat trout in a mountain stream in Montana, U.S.A. Japanese Journal of Ichthyology 39: 211-217.

Newman, R. M., 1987. Comparison of encounter model predictions with observed size-selectivity by stream trout. Journal of North American Benthological Society 6: 56-64.

Poff, N. L., J. D. Olden, N. K. M. Vieira, D. S. Finn, M. P. Simmons, \& B. C. Kondratieff, 2006. Functional trait niches of North American lotic insects: traits-based ecological applications in light of phylogenetic relationships. Journal of the North American Benthological Society 25: 730-755.

Poulton, B. C., D. P. Monda, D. F. Woodward, M. L. Wildhaber, \& W. G. Brumbaugh, 1995. Relations between benthic community structure and metals concentrations in aquatic macroinvertebrates: Clark Fork River, Montana. Journal of Freshwater Ecology 10: 277-293.

Quinn, M. R., X. Feng, C. L. Folt, \& C. P. Chamberlain, 2003. Analyzing trophic transfer of metals in stream food webs using nitrogen isotopes. Science of the Total Environment 317: 73-89.

R Core Team, 2015. R: A Language and Environment for Statistical Computing. R Foundation for Statistical Computing. , https://www.r-project.org/.

Rader, R. B., 1997. A functional classification of the drift: traits that influence invertebrate availability to salmonids. Canadian Journal of Fisheries and Aquatic Sciences 54: 1211-1234.

Schemel, L. E., B. A. Kimball, \& K. E. Bencala, 2000. Colloid formation and metal transport through two 
mixing zones affected by acid mine drainage near Silverton, Colorado. Applied Geochemistry 15: 10031018.

Schmitz, D., J. Mason, M. Blank, \& J. Cahoon, 2010. Channel response assessment for the upper Blackfoot River. Montana Department of Natural Resources and Conservation 1-46.

Song, J., X. Yang, J. Zhang, Y. Long, Y. Zhang, \& T. Zhang, 2015. Assessing the variability of heavy metal concentrations in liquid-solid two-phase and related environmental risks in the Weihe River of Shaanxi Province, China. International Journal of Environmental Research and Public Health 12: 8243-8262.

U.S. Environmental Protection Agency, 1991. Methods for the determination of metals in environmental samples. Washington, DC.

U.S. Environmental Protection Agency, 2007. Aquatic Life Ambient Freshwater Quality Criteria - Copper. Washington, DC.

U.S. Environmental Protection Agency, 2016. Aquatic Life Ambient Water Quality Criteria - Cadmium. Washington, DC.

U.S. Fish and Wildlife Service, 1993. Milltown endangerment assessment project: effects of metalcontaminated sediment, water, and diet on aquatic organisms. National Fisheries Contaminant Research Center, Columbia, MO.

Vandeberg, G. S., C. W. Martin, \& G. M. Pierzynski, 2011. Spatial distribution of trace elements in floodplain alluvium of the upper Blackfoot River, Montana. Environmental Earth Sciences 62: 15211534.

Ward, J. V, \& B. C. Kondratieff, 1992. An illustrated guide to the mountain stream insects of Colorado. University Press of Colorado, Fort Collins.

Wolman, G. M., 1954. A method of sampling coarse river-bed material. Transactions of the American Geophysical Union 35.

Woodward, D. F., W. G. Brumbaugh, A. J. Lelonay, E. E. Little, \& C. . Smith, 1994. Effects on rainbow trout fry of a metals-contaminated diet of benthic invertebrates from the Clark Fork River, Montana.

Transactions of the American Fisheries Society 123: 51-62. 


\section{Table Captions}

Table 1: Average metals concentrations for three sampling reaches at each site and the percent contribution of each metal to the overall Cumulative Sediment Criterion Unit (CSCU) for each site.

Table 2: AIC model selection results for multiple regression models. The full model is reported first for each year and response variable, followed by subsequent selection steps. The final model selected is in bold text. Abbreviations: medianCSCU = median Cumulative Sediment Criterion Units, $p H$ and temp $=$ acidity and water temperature measured at each site, fines $=$ percent surface fines in substrate, $D 50=$ $50 \%$ particle size distribution in millimeters, drain_area $=$ drainage area from sampling point in $\mathrm{km}^{2}$

Table 3: Multiple regression model results for four community composition metrics (invertebrate density, species richness, and number of trophic links). Abbreviations: medianCSCU = median Cumulative Sediment Criterion Units, $\mathrm{pH}$ and temp = acidity and water temperature measured at each site, fines $=$ percent surface fines in substrate, $D 50=50 \%$ particle size distribution in millimeters, drain_area $=$ drainage area from sampling point in $\mathrm{km}^{2}$.

Table 4: Simple linear regression model results for selected invertebrate functional groups (collectorfilterers, scrapers, weak propensity-to-drift, strong propensity-to-drift). Abbreviations: PropCF = proportion of invertebrates in the collector-filterer functional feeding group (FFG), PropSC = proportion of invertebrates in the scraper FFG, PropWeak = proportion of invertebrates in the weak propensity-todrift, PropStrong = proportion of invertebrates with a strong propensity-to-drift, Group_metal = metal concentrations $(\mathrm{mg} / \mathrm{kg}$ ) for arsenic, cadmium, copper, and zinc in collector-filterer invertebrates (CF_metal), scraper invertebrates (SC_metal), invertebrates with a weak propensity-to-drift (Weak_metal), or invertebrates with a strong propensity-to-drift (Strong_metal).

Table 5: Table 5: Metals concentrations (average ( $\mathrm{min} / \mathrm{max})$ ) and functional feeding groups for all invertebrates sampled for metals analyses in 2009 and 2010. Propensity-to-drift category: $W=W e a k, M$ $=$ Medium, $\mathrm{S}=$ Strong.

\section{Figure Captions}

Figure 1. Sites sampled in the upper Blackfoot River for metals contamination in sediment and aquatic organisms. These included seven mining-impacted sites: six on the Blackfoot River downstream of the Mike Horse Dam (B0, B1, B2, B3, B4, B5) and one tributary site Shave Gulch (SG), and eight reference sites (Anaconda Creek - AC, Beartrap Creek - BC, Cadotte Creek - CD, Copper Creek - CuC, Meadow Creek - MC, Snowbank Creek - SC, Willow Creek - WC1 \& WC2) with low known mining impacts.

Figure 2. (a) Boxplot of Cumulative Criteria Units (CSCU) including arsenic, cadmium, chromium, copper, lead, and zinc in sediment at each site sampled in 2009 and 2010. The mining-impacted sites downstream of the Mike Horse Dam (B0, B1, B2, B3, B4 and tributary SG) had higher contaminant values than the eight reference sites $(A C, B C, C D, C U C, M C, S C, W C 1, W C 2)$. Metals concentrations in sediment were not collected from site B5. (b) Median CSCU in sediment declined with distance from Mike Horse Dam, which failed in 1975 and released tailings downstream, for the Blackfoot River mainstem sites.

Figure 3. Invertebrate community metrics (density as number per $\mathrm{m}^{2}$, species richness, and number of trophic links) versus sediment contamination. All four metrics declined significantly with increasing (In) 
median CSCU in sediment samples for both years $(p<0.01)$. Adjusted $R^{2} 2009 / 2010$ : Density $=0.7 / 0.6$, Species Richness $=0.7 / 0.7$, Number of Trophic Links $=0.7 / 0.7$.

Figure 4. (a) Metals contamination in sediment by functional feeding group (FFG): Proportions of scrapers in aquatic invertebrate composition samples declined with sediment cumulative criteria units ((In) median CSCU) whereas the proportions of collector-filterers increased or had no change with (In) median CSCU across upper Blackfoot River sites sampled in 2009 and 2010. R 2009/2010: Scrapers = $0.2 / 0.4$, Collector-filterers $=0.2 / 0.0$ (b) Metals concentrations in scraper and collector-filterer invertebrates increased with (In) median CSCU. $\mathrm{R}^{2} \mathrm{CF} / \mathrm{SC}$ : arsenic $=0.03 / 0.02$, cadmium $=0.03 / 0.1$, copper $=0.4 / 0.3$, zinc $=0.2 / 0.1$.

Figure 5. Metals contamination in sediment stratified with respect to invertebrate propensity-to-drift: (a) Proportion of invertebrates with a weak propensity-to-drift declined in both years with increasing sediment CSCU, while invertebrates with a strong propensity-to-drift increased in both years. $\mathrm{R}^{2}$ 2009/2010: Weak $=0.5 / 0.3$, Strong $=0.3 / 0.2$ (b) Contaminant levels of drifting aquatic insects increased with sediment CSCU in both years and drift categories, but with considerable variation across the range of contamination levels. $\mathrm{R}^{2}$ Strong/Weak: arsenic $=0.02 / 0.04$, cadmium $=0.1 / 0.04$, copper $=0.2 / 0.3$, zinc $=0.1 / 0.2$.

Figure 6. Metal exposure values (EV) based on availability of metal-contaminated aquatic invertebrates varied with sediment CSCU. Except for one outlier at a reference site, our moderately contaminated sites had some of the highest exposure values due to the effect of higher aquatic invertebrate densities and moderate metals concentrations.

Figure 7. Metals concentrations in fish exhibit a similar pattern as invertebrate exposure values, with the highest fish metals concentrations observed at moderately contaminated sites (median CSCU $=65$ ). 
Table 1: Average metals concentrations for three sampling reaches in sediment samples at each site and the percent contribution of each metal to the overall Cumulative Sediment Criterion Unit (CSCU) for each site.

\begin{tabular}{|c|c|c|c|c|c|c|c|c|c|c|c|c|c|c|c|c|}
\hline & Site $^{\mathrm{a}}$ & Year $^{\mathrm{b}}$ & $\begin{array}{c}\text { Drainage } \\
\text { Area } \\
\left(\mathrm{km}^{2}\right) \\
\end{array}$ & $\begin{array}{c}\mathrm{mg} / \mathrm{k} \\
\mathrm{g}\end{array}$ & $\%$ & $\begin{array}{c}\mathrm{mg} / \mathrm{k} \\
\mathrm{g}\end{array}$ & $\%$ & $\begin{array}{c}\mathrm{mg} / \\
\mathrm{kg}\end{array}$ & $\%$ & $\mathrm{mg} / \mathrm{kg}$ & $\%$ & $\mathrm{mg} / \mathrm{kg}$ & $\%$ & $\mathrm{mg} / \mathrm{kg}$ & $\%$ & $\operatorname{cscu}$ \\
\hline \multirow{7}{*}{$\begin{array}{l}\mathbb{\Xi} \\
\stackrel{\Xi}{\mathrm{g}} \\
\underline{\underline{\xi}}\end{array}$} & BO & 2010 & 5 & 184.3 & 9.8 & 27.8 & 9.7 & 11.4 & 0.2 & 1168.4 & 13.8 & 3021.5 & 41.5 & 6594.6 & 24.9 & 59.4 \\
\hline & B1 & 2009 & 14 & 214.4 & 9.7 & 18.2 & 5.4 & 10.4 & 0.2 & 1031.1 & 10.3 & 4383.3 & 62.8 & 3630.4 & 11.7 & 67.4 \\
\hline & B2 & 2009 & 23 & 171.9 & 10.8 & 18.7 & 8.9 & 11.5 & 0.2 & 969.4 & 15.0 & 2696.8 & 47.2 & 3556.7 & 19.5 & 44.6 \\
\hline & B2 & 2010 & 23 & 123.8 & 5.9 & 45.8 & 14.2 & 16.8 & 0.3 & 1489.0 & 16.3 & 2601.5 & 32.5 & 8743.5 & 29.4 & 64.8 \\
\hline & B3 & 2009 & 36 & 54.4 & 4.2 & 26.5 & 13.7 & 10.5 & 0.2 & 1305.9 & 22.5 & 1181.9 & 23.8 & 6303.9 & 35.4 & 38.8 \\
\hline & B3 & 2010 & 36 & 62.2 & 4.2 & 29.8 & 13.3 & 14.3 & 0.3 & 1494.8 & 22.6 & 1503.2 & 27.4 & 7001.4 & 32.0 & 44.5 \\
\hline & SG & 2010 & 7 & 31.7 & 13.0 & 3.3 & 9.5 & 17.4 & 2.1 & 210.2 & 20.6 & 376.1 & 37.6 & 565.3 & 18.0 & 7.4 \\
\hline \multirow{7}{*}{ 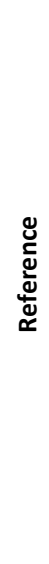 } & AC & 2009 & 7 & 19.7 & 31.3 & 0.2 & 2.1 & 11.9 & 5.6 & 85.4 & 30.2 & 46.2 & 18.7 & 105.1 & 12.0 & 1.9 \\
\hline & AC & 2010 & 7 & 20.9 & 30.5 & 0.2 & 2.0 & 16.9 & 7.7 & 99.0 & 33.9 & 33.7 & 13.3 & 114.2 & 12.6 & 2.0 \\
\hline & $B C$ & 2009 & 2 & 17.5 & 35.5 & 0.2 & 2.7 & 6.4 & 3.9 & 40.9 & 18.3 & 44.2 & 23.2 & 111.7 & 16.4 & 1.5 \\
\hline & $B C$ & 2010 & 2 & 20.4 & 30.1 & 0.2 & 2.2 & 10.8 & 4.7 & 77.6 & 28.4 & 43.4 & 17.5 & 155.5 & 16.5 & 1.9 \\
\hline & $C D$ & 2009 & 7 & 11.1 & 34.6 & 0.2 & 4.2 & 14.8 & 13.8 & 36.5 & 25.1 & 9.4 & 7.5 & 66.2 & 14.9 & 1.0 \\
\hline & CuC & 2010 & 34 & 15.7 & 34.4 & 0.2 & 2.9 & 12.9 & 8.3 & 70.0 & 34.0 & 15.2 & 8.6 & 73.7 & 11.8 & 1.4 \\
\hline & $\mathrm{MC}$ & 2009 & 1 & 34.0 & 23.0 & 2.2 & 8.8 & 12.3 & 2.5 & 113.5 & 17.3 & 94.4 & 17.3 & 664.7 & 32.6 & 4.5 \\
\hline
\end{tabular}

a. Site abbreviations are as follows: B0, B1, B2, B3, B4, B5 = mainstem Blackfoot River, SG = Shave Gulch, AC=Anaconda Creek, $\mathrm{BC}=$ Beartrap Creek, CD =Cadotte Creek, CuC = Copper Creek, MC = Meadow Creek, SC = Snowbank Creek, WC1 \& WC2 = Willow Creek. Site locations are shown in Figure 1.

b. Adjustments in our sampling between 2009 and 2010 resulted in substitution among some of the reference sites such that these sites were only surveyed in one year. 
Table 2: Akaike information criterion (AIC) model selection results for multiple regression models. The full model is reported first for each year and response variable, followed by subsequent selection steps. The final model selected is in bold text.

\begin{tabular}{|c|c|c|c|c|c|c|}
\hline Year & Step & Model & $\begin{array}{c}\text { Residual } \\
\text { df }\end{array}$ & $\begin{array}{c}\text { Residual } \\
\text { Dev. }\end{array}$ & AIC & $\Delta \mathrm{AIC}$ \\
\hline \multirow{4}{*}{2009} & 1 & density $\sim$ medianCSCU + pH + temp + drain_area + D50 + fines & 20 & 6.72 & -23.6 & 1.8 \\
\hline & 2 & density medianCSCU + pH + temp + D50 + fines & 21 & 6.90 & -24.8 & 0.5 \\
\hline & 3 & density $\sim$ medianCSCU + pH + temp + D50 & 22 & 7.33 & -25.2 & 0.2 \\
\hline & 4 & density medianCSCU + pH + temp & 23 & 7.85 & -25.4 & 0.0 \\
\hline \multirow{4}{*}{2010} & 1 & density medianCSCU + temp + D50 + fines + drain_area & 10 & 5.15 & -6.0 & 3.3 \\
\hline & 2 & density $\sim$ medianCSCU + temp + D50 + fines & 10 & 5.15 & -6.0 & 3.3 \\
\hline & 3 & density $\sim$ medianCSCU + D50 + fines & 11 & 5.32 & -7.5 & 1.8 \\
\hline & 4 & density medianCSCU + fines & 12 & 5.40 & -9.3 & 0.0 \\
\hline \multirow{3}{*}{2009} & 1 & richness $\sim$ medianCSCU + pH + temp + drain_area + D50 + fines & 20 & 5.75 & -27.8 & 2.1 \\
\hline & 2 & richness $\sim$ medianCSCU $+p H+$ temp + D50 + fines & 21 & 5.78 & -29.6 & 0.2 \\
\hline & 3 & richness $\sim$ medianCSCU + pH + temp + fines & 22 & 6.16 & -29.9 & 0.0 \\
\hline \multirow{3}{*}{2010} & 1 & richness $\sim$ medianCSCU + temp + D50 + fines + drain_area & 10 & 3.08 & -13.8 & 1.8 \\
\hline & 2 & richness $\sim$ medianCSCU + temp + D50 + fines & 10 & 3.08 & -13.8 & 1.8 \\
\hline & 3 & richness $\sim$ medianCSCU + D50 + fines & 11 & 3.12 & -15.5 & 0.0 \\
\hline \multirow{3}{*}{2009} & 1 & links medianCSCU + pH + temp + drain_area + D50 + fines & 20 & 6.14 & -26.0 & 3.6 \\
\hline & 2 & links $\sim$ medianCSCU + pH + temp + drain_area + fines & 21 & 6.17 & -27.9 & 1.7 \\
\hline & 3 & links medianCSCU + pH + drain_area + fines & 22 & 6.23 & -29.6 & 0.0 \\
\hline \multirow{3}{*}{2010} & 1 & links $\sim$ medianCSCU + temp + D50 + fines + drain_area & 10 & 3.72 & -10.9 & 2.0 \\
\hline & 2 & links $\sim$ medianCSCU + temp + D50 + fines & 10 & 3.72 & -10.9 & 2.0 \\
\hline & 3 & links medianCSCU + D50 + fines & 11 & 3.72 & -12.9 & 0.0 \\
\hline
\end{tabular}

Abbreviations: medianCSCU = median Cumulative Sediment Criterion Units, $p H$ and temp $=$ acidity and water temperature measured at each site, fines = percent surface fines in substrate, $D 50=$ median bed-material size in $\mathrm{mm}$, drain_area $=$ drainage area upstream of sampling point in $\mathrm{km}^{2}$, density $=$ invertebrate density, richness $=$ species richness, links = number of trophic links 
Table 3: Multiple regression model results for three community composition metrics (invertebrate density, species richness, and number of trophic links).

\begin{tabular}{|c|c|c|c|c|c|c|c|c|c|}
\hline Year & $\begin{array}{c}\text { Response } \\
\text { variable }\end{array}$ & $\begin{array}{c}\text { Predictors in } \\
\text { the model }\end{array}$ & Estimate & SE & $\begin{array}{l}\text { Partial } \\
\text { p value }\end{array}$ & $\begin{array}{r}\text { Model } p \\
\text { value } \\
\end{array}$ & F statistic & $\mathbf{R}^{2}$ & $\begin{array}{c}\text { Adj. } \\
\mathrm{R}^{2}\end{array}$ \\
\hline \multirow[t]{3}{*}{2009} & Density & medianCSCU & -0.60 & 0.12 & $<0.001$ & $<0.001$ & $F(3,23)=17.73$ & 0.70 & 0.66 \\
\hline & & $\mathrm{pH}$ & 0.43 & 0.12 & 0.001 & & & & \\
\hline & & temp & 0.24 & 0.11 & 0.049 & & & & \\
\hline \multirow[t]{2}{*}{2010} & Density & medianCSCU & -0.60 & 0.18 & 0.006 & 0.003 & $F(2,12)=9.56$ & 0.61 & 0.55 \\
\hline & & fines & -0.41 & 0.18 & 0.044 & & & & \\
\hline \multirow[t]{4}{*}{2009} & Richness & medianCSCU & -0.79 & 0.14 & $<0.001$ & $<0.001$ & $F(4,22)=17.7$ & 0.76 & 0.72 \\
\hline & & $\mathrm{pH}$ & 0.36 & 0.12 & 0.009 & & & & \\
\hline & & temp & 0.17 & 0.10 & 0.117 & & & & \\
\hline & & fines & 0.29 & 0.15 & 0.062 & & & & \\
\hline \multirow[t]{3}{*}{2010} & Richness & medianCSCU & -0.58 & 0.15 & 0.003 & $<0.001$ & $F(3,11)=12.78$ & 0.78 & 0.72 \\
\hline & & D50 & 0.38 & 0.22 & 0.121 & & & & \\
\hline & & fines & -0.74 & 0.23 & 0.007 & & & & \\
\hline \multirow[t]{4}{*}{2009} & Links & medianCSCU & -0.81 & 0.14 & $<0.001$ & $<0.001$ & $F(4,22)=17.45$ & 0.76 & 0.72 \\
\hline & & $\mathrm{pH}$ & 0.33 & 0.12 & 0.014 & & & & \\
\hline & & drain_area & 0.24 & 0.11 & 0.035 & & & & \\
\hline & & fines & 0.26 & 0.15 & 0.107 & & & & \\
\hline \multirow[t]{3}{*}{2010} & Links & medianCSCU & -0.54 & 0.16 & 0.007 & 0.002 & $F(3,11)=10.14$ & 0.73 & 0.66 \\
\hline & & D50 & 0.47 & 0.24 & 0.080 & & & & \\
\hline & & fines & -0.78 & 0.25 & 0.010 & & & & \\
\hline
\end{tabular}

Abbreviations: medianCSCU $=$ median Cumulative Sediment Criterion Units, $p H$ and temp $=$ acidity and water temperature measured at each site, fines $=$ percent surface fines in substrate, $D 50=50 \%$ particle size distribution in millimeters, drain_area $=$ drainage area from sampling point in $\mathrm{km}^{2}$. 
Table 4: Simple linear regression model results for selected invertebrate functional groups (collectorfilterers, scrapers, weak propensity-to-drift, strong propensity-to-drift)

\begin{tabular}{|c|c|c|c|c|c|}
\hline Year & $\begin{array}{c}\text { Response } \\
\text { variable }\end{array}$ & $\begin{array}{c}\text { Explanatory } \\
\text { variable }\end{array}$ & $\begin{array}{r}\text { Model } p \\
\text { value } \\
\end{array}$ & F statistic & $\mathbf{R}^{\mathbf{2}}$ \\
\hline 2009 & PropCF & In(medianCSCU) & 0.040 & $F(1,27)=4.64$ & 0.15 \\
\hline 2010 & PropCF & In(medianCSCU) & 0.961 & $F(1,25)=0.002$ & 0.00 \\
\hline 2009 & PropsC & In(medianCSCU) & 0.014 & $F(1,27)=6.96$ & 0.21 \\
\hline 2010 & PropSC & In(medianCSCU) & $<0.001$ & $F(1,25)=15.33$ & 0.38 \\
\hline 2009 & PropWeak & In(medianCSCU) & $<0.001$ & $F(1,28)=24.55$ & 0.47 \\
\hline 2010 & PropWeak & In(medianCSCU) & 0.005 & $F(1,25)=9.7$ & 0.28 \\
\hline 2009 & PropStrong & In(medianCSCU) & 0.002 & $F(1,28)=11.44$ & 0.29 \\
\hline 2010 & PropStrong & In(medianCSCU) & 0.026 & $F(1,25)=5.62$ & 0.18 \\
\hline Both & CF_As & In(medianCSCU) & 0.526 & $F(1,16)=0.42$ & 0.03 \\
\hline Both & CF_Cd & In(medianCSCU) & 0.500 & $F(1,16)=0.48$ & 0.03 \\
\hline Both & $\mathrm{CF}_{-} \mathrm{Cu}$ & In(medianCSCU) & 0.004 & $F(1,16)=11.38$ & 0.42 \\
\hline Both & CF_Zn & In(medianCSCU) & 0.077 & $F(1,16)=3.58$ & 0.18 \\
\hline Both & SC_As & In(medianCSCU) & 0.407 & $F(1,35)=0.71$ & 0.02 \\
\hline Both & SC_Cd & In(medianCSCU) & 0.300 & $F(1,35)=1.11$ & 0.03 \\
\hline Both & $\mathrm{SC} \_\mathrm{Cu}$ & In(medianCSCU) & $<0.001$ & $F(1,35)=16.92$ & 0.33 \\
\hline Both & SC_Zn & In(medianCSCU) & 0.005 & $F(1,35)=9.03$ & 0.21 \\
\hline Both & Strong_As & In(medianCSCU) & 0.256 & $F(1,58)=1.31$ & 0.02 \\
\hline Both & Strong_Cd & In(medianCSCU) & 0.003 & $F(1,58)=9.59$ & 0.14 \\
\hline Both & Strong_Cu & In(medianCSCU) & $<0.001$ & $F(1,58)=12.4$ & 0.18 \\
\hline Both & Strong_Zn & In(medianCSCU) & 0.014 & $F(1,58)=6.48$ & 0.10 \\
\hline Both & Weak_As & In(medianCSCU) & 0.112 & $F(1,62)=2.6$ & 0.04 \\
\hline Both & Weak_Cd & In(medianCSCU) & 0.134 & $F(1,62)=2.31$ & 0.04 \\
\hline Both & Weak_Cu & In(medianCSCU) & $<0.001$ & $F(1,62)=26.08$ & 0.30 \\
\hline Both & Weak_Zn & In(medianCSCU) & 0.001 & $F(1,62)=11.46$ & 0.16 \\
\hline
\end{tabular}

Abbreviations: PropCF = proportion of invertebrates in the collector-filterer functional feeding group (FFG), PropSC = proportion of invertebrates in the scraper FFG, PropWeak = proportion of invertebrates in the weak propensity-to-drift, PropStrong = proportion of invertebrates with a strong propensity-to-drift, Group_metal = metal concentrations $(\mathrm{mg} / \mathrm{kg})$ for arsenic, cadmium, copper, and zinc in collector-filterer invertebrates (CF_metal), scraper invertebrates (SC_metal),

invertebrates with a weak propensity-to-drift (Weak_metal), or invertebrates with a strong propensity-to-drift (Strong_metal). 
Table 5: Metals concentrations (average ( $\mathrm{min} / \mathrm{max})$ ) and functional feeding groups for all invertebrates sampled for metals analyses in 2009 and 2010. Propensity-to-drift category: $W=$ Weak, $M=$ Medium, $S$ = Strong.

\begin{tabular}{|c|c|c|c|c|c|}
\hline Taxon & $\begin{array}{l}\text { Functional feeding } \\
\text { group / Drift category }\end{array}$ & $\begin{array}{l}\text { As }(\mathrm{mg} / \mathrm{kg}) \\
\text { avg. }(\mathrm{min} / \max )\end{array}$ & $\begin{array}{l}\mathrm{Cd}(\mathrm{mg} / \mathrm{kg}) \\
\operatorname{avg} .(\min / \max )\end{array}$ & $\begin{array}{l}\mathrm{Cu}(\mathrm{mg} / \mathrm{kg}) \\
\operatorname{avg} .(\min / \max )\end{array}$ & $\begin{array}{l}\mathrm{Zn}(\mathrm{mg} / \mathrm{kg}) \\
\operatorname{avg} .(\min / \max )\end{array}$ \\
\hline Parapsyche elsis & Collector-Filterer/S & $1.6(0.3 / 18.4)$ & $2.5(0.4$ / 9.8) & $171.6(14.6$ / 1331.4) & 1124.5 (118.8 / 9280) \\
\hline Hesperoperla pacifica & Predator / W & $0.3(0.3 / 0.3)$ & $8.7(0.4 / 82.2)$ & 101.9 (37.3 / 364.8) & 564.9 (160.9 / 1396) \\
\hline Drunella coloradensis & Scraper / W & $0.8(0.2 / 7.2)$ & $9.9(0 / 97.7)$ & 221.9 (3.2 / 1532.7) & 1459 (51.8 / 8691) \\
\hline Limnephilidae & Shredder / W & $3.2(0.3 / 32.5)$ & $7.2(0.4$ / 31.5) & 314.9 (29.4 / 1403.7) & 1217.7 (161 / 3163.5) \\
\hline Sweltsa & Predator / M & $2.8(0.3 / 7.9)$ & $5.3(0.4$ / 8.9) & 186.5 (170.6 / 214) & 1767 (1080 / 2126) \\
\hline Chironomidae & Collector-Gatherer / S & $4.4(0.3 / 12.7)$ & $8.9(7.4 / 11.1)$ & 244.3 (151.5 / 343.9) & 1490.3 (862 / 2091) \\
\hline Isoperla & Predator / S & $3.1(0.3 / 11.2)$ & $4.7(0.4 / 13.4)$ & 129.7 (7.3 / 226.5) & 937.7 (32.3 / 3209) \\
\hline Rhyacophila & Predator / S & $0.9(0.2 / 25.9)$ & $4(0 / 32.9)$ & 101.7 (0.5 / 1323.5) & 899.9 (29.3 / 5092.3) \\
\hline Epeorus & Scraper / W & $0.3(0.3 / 0.3)$ & $1.3(0.4$ / 4.9) & 146.2 (51.9 / 275.6) & 455.6 (225.9 / 760) \\
\hline Claassenia sabulosa & Predator / W & $0.4(0.2 / 0.8)$ & $1.3(0 / 2.4)$ & 89.4 (29 / 316.3) & 916.9 (174 / 3092.1) \\
\hline Neoporus & Predator / \#N/A & $0.3(0.3 / 0.3)$ & $21.8(21.8$ / 21.8) & 684.6 (684.6 / 684.6) & 3698 (3698 / 3698) \\
\hline Brachycentrus & Collector-Filterer/S & $9.2(0.2 / 38.4)$ & $11.5(0 / 24.6)$ & $82(0.5 / 172)$ & 3645.5 (312 / 7200) \\
\hline Arctopsyche grandis & Predator / S & $0.2(0.2 / 0.3)$ & $4.4(0 / 13.6)$ & $35.5(0.5 / 114.8)$ & 1244.8 (215 / 3840) \\
\hline
\end{tabular}


Figure 1. Sites sampled in the upper Blackfoot River for metals contamination in sediment and aquatic organisms. These included seven mining-impacted sites: six on the Blackfoot River downstream of the Mike Horse Dam (B0, B1, B2, B3, B4, B5) and one tributary site Shave Gulch (SG), and eight reference sites (Anaconda Creek - AC, Beartrap Creek - BC, Cadotte Creek - CD, Copper Creek - CuC, Meadow Creek - MC, Snowbank Creek - SC, Willow Creek - WC1 \& WC2) with low known mining impacts.

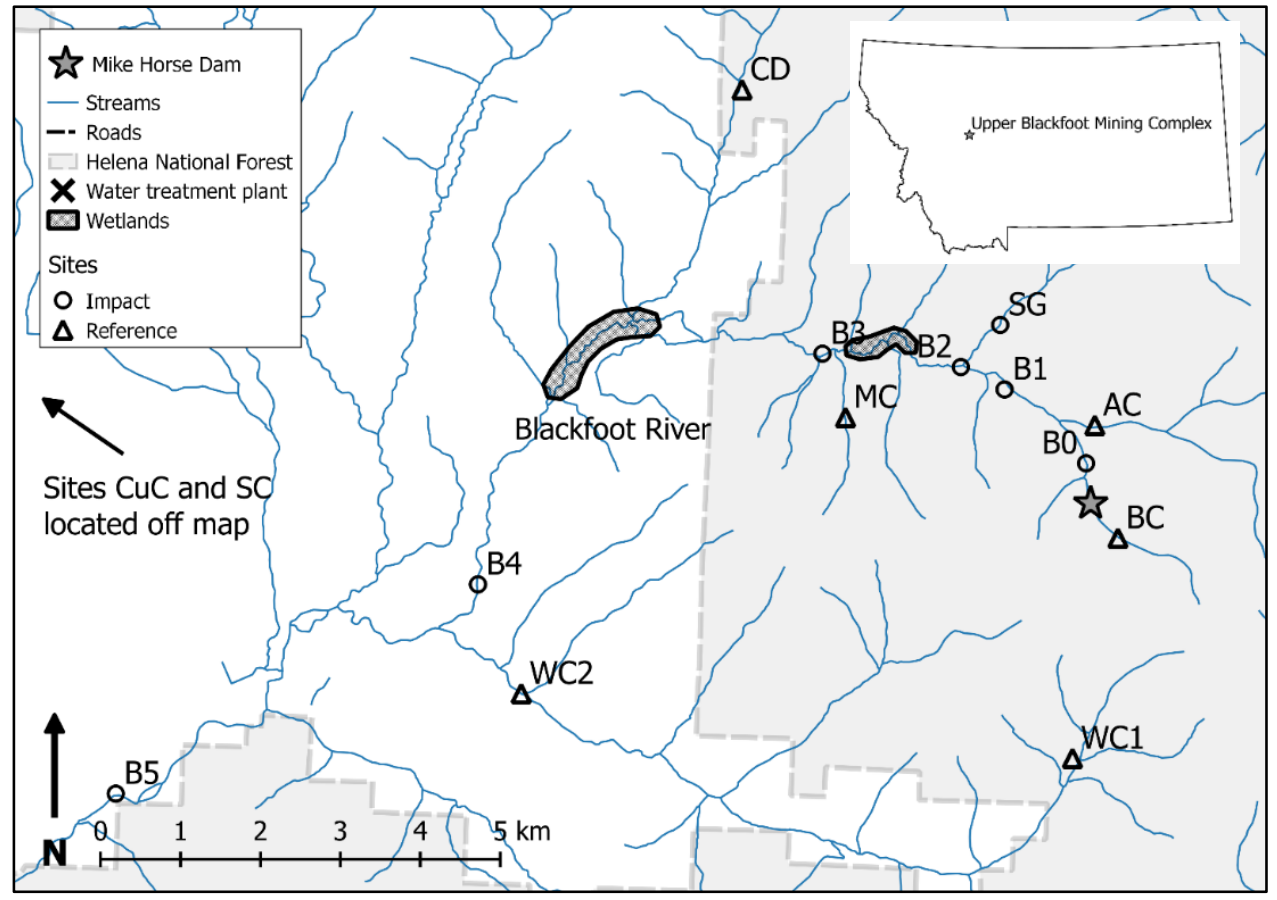

Page 29 of 34 
Figure 2. (a) Boxplot of Cumulative Sediment Criteria Units (CSCU) including arsenic, cadmium, chromium, copper, lead, and zinc in sediment at each site sampled in 2009 and 2010. The miningimpacted sites downstream of the Mike Horse Dam (B0, B1, B2, B3, B4 and tributary SG) had higher contaminant values than the eight reference sites ( $A C, B C, C D, C U C, M C, S C, W C 1, W C 2)$. Metals concentrations in sediment were not collected from site B5. (b) Median CSCU in sediment declined with distance from Mike Horse Dam, which failed in 1975 and released tailings downstream, for the Blackfoot River mainstem sites.
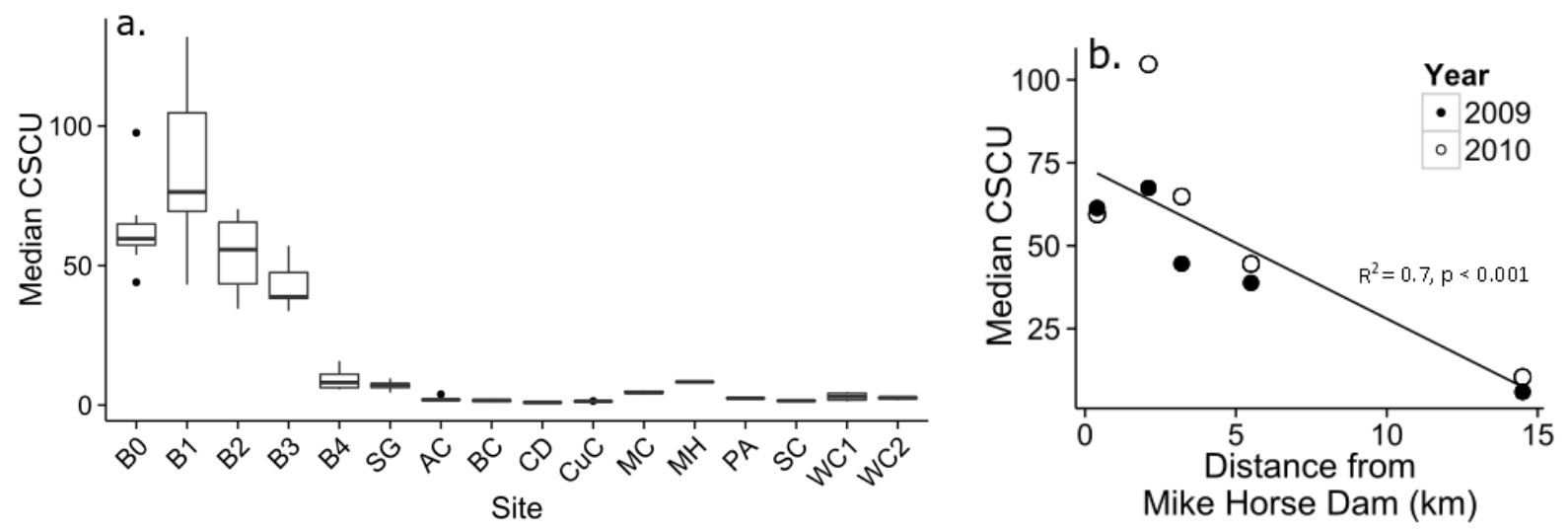
Figure 3. Invertebrate community metrics (density as number per $\mathrm{m}^{2}$, species richness, and number of trophic links) versus sediment contamination. All three metrics declined significantly with increasing (In) median CSCU in sediment samples for both years $(p<0.01)$. Adjusted $R^{2} 2009 / 2010$ : Density $=0.7 / 0.6$, Species Richness $=0.7 / 0.7$, Number of Trophic Links $=0.7 / 0.7$.
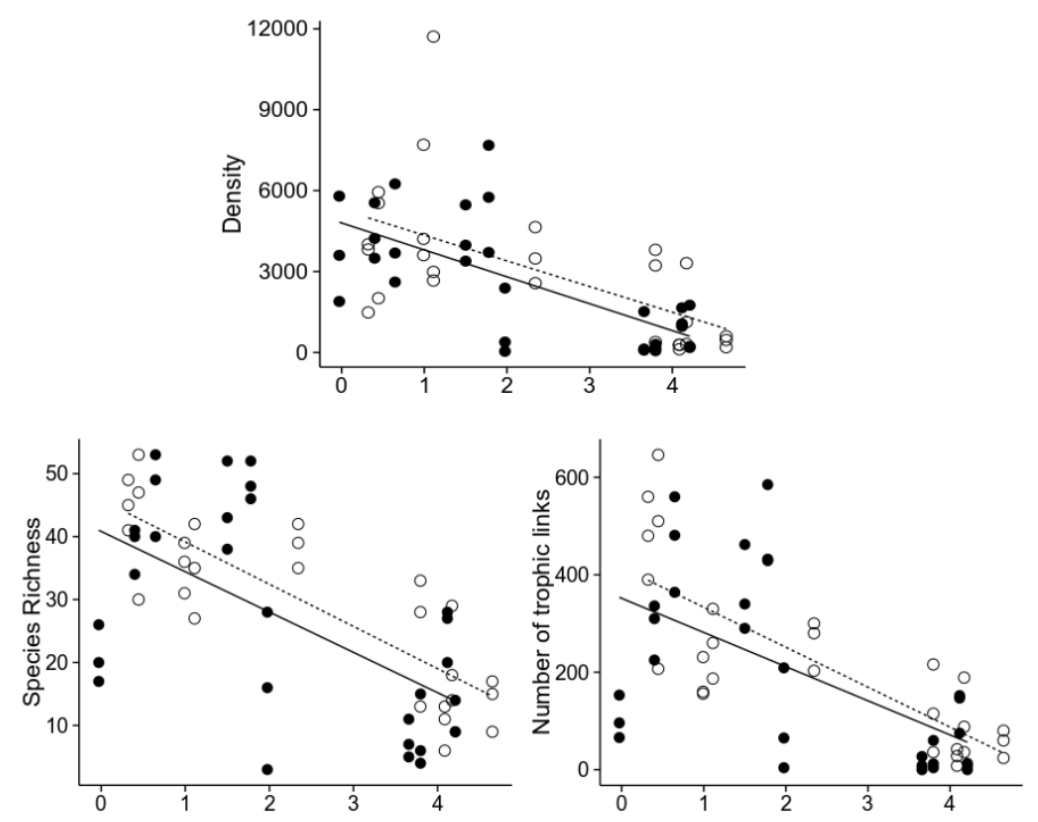

(In) Median CSCU

Year $\rightarrow 2009 \cdot \cdot \cdot 2010$ 
Figure 4. (a) Metals contamination in sediment by functional feeding group (FFG): Proportions of scrapers in aquatic invertebrate composition samples declined with cumulative sediment criteria units ((In) median CSCU) whereas the proportions of collector-filterers increased or had no change with (In) median CSCU across upper Blackfoot River sites sampled in 2009 and 2010. $R^{2}$ 2009/2010: Scrapers = $0.2 / 0.4$, Collector-filterers $=0.2 / 0.0$ (b) Metals concentrations in scraper (SC) and collector-filterer (CF) invertebrates increased with (In) median CSCU. $\mathrm{R}^{2} \mathrm{CF} / \mathrm{SC}$ : arsenic $=0.03 / 0.02$, cadmium $=0.03 / 0.1$, copper $=0.4 / 0.3$, zinc $=0.2 / 0.1$.
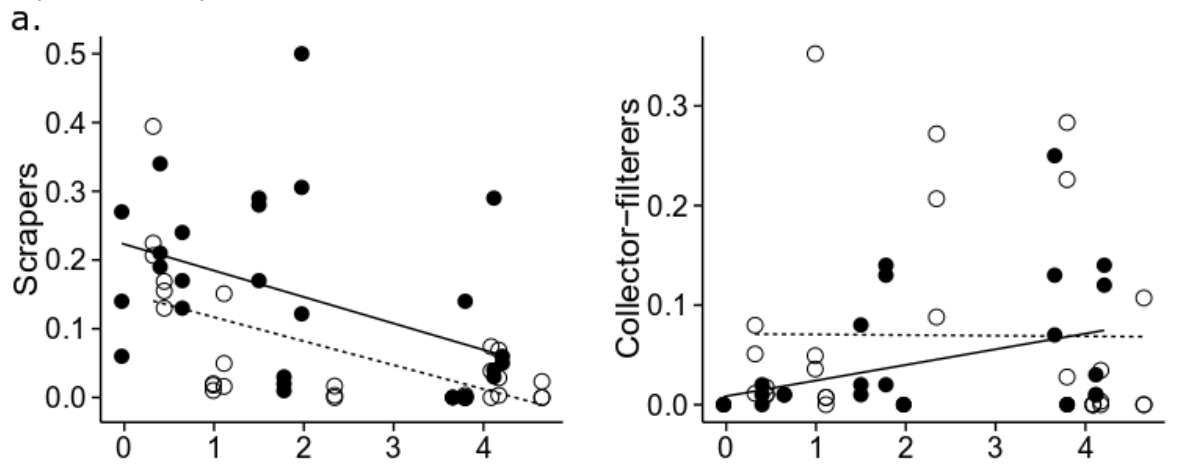

(In) Median CSCU

Year $\rightarrow 2009 \cdot \bullet \cdot 2010$

b.
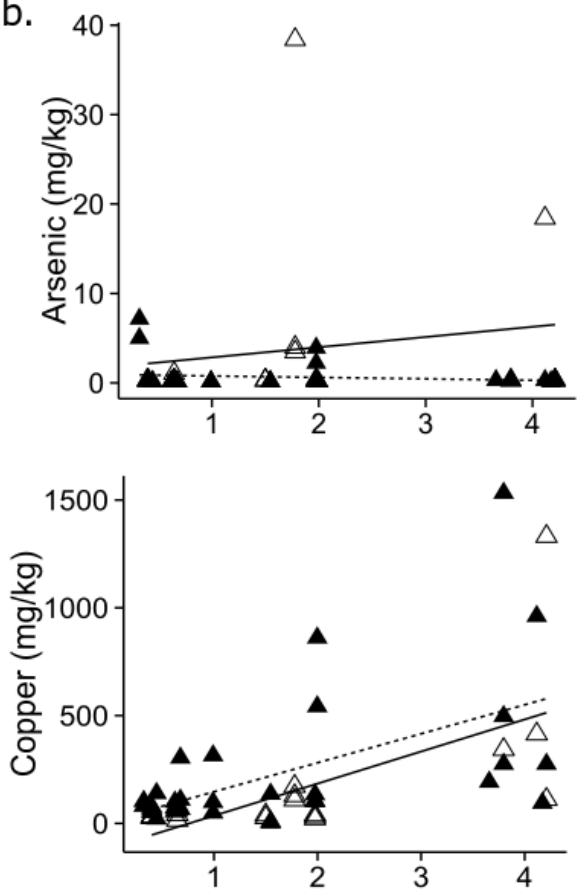
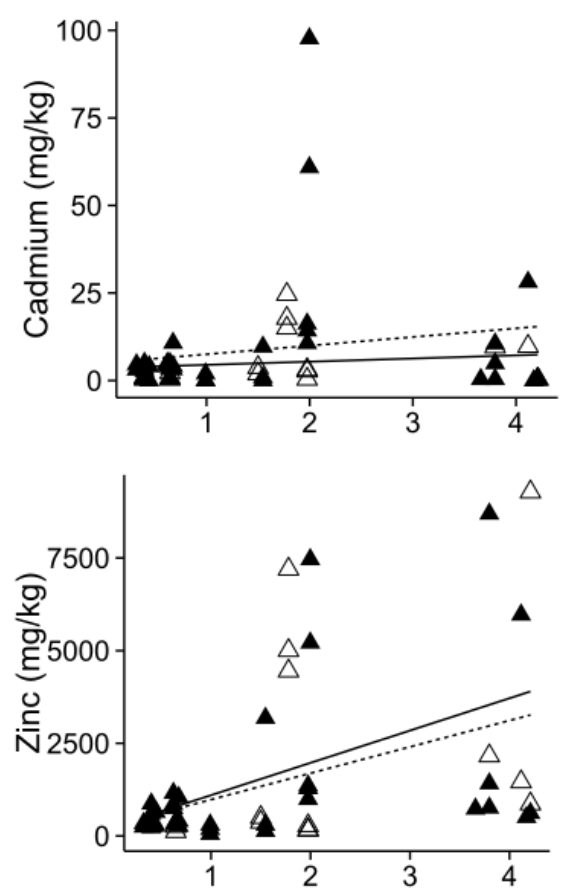

(In) Median CSCU

FFG $\triangle$ Collector-filterer $-\star$ Scraper 
Figure 5. Metals contamination in sediment stratified with respect to invertebrate propensity-to-drift: (a) Proportion of invertebrates with a weak propensity-to-drift declined in both years with increasing sediment CSCU, while proportion of invertebrates with a strong propensity-to-drift increased in both years. $R^{2}$ 2009/2010: Weak $=0.5 / 0.3$, Strong $=0.3 / 0.2$ (b) Contaminant levels of drifting aquatic insects increased with sediment CSCU in both years and drift categories, but with considerable variation across the range of contamination levels. $R^{2}$ Strong/Weak: arsenic $=0.02 / 0.04$, cadmium $=0.1 / 0.04$, copper $=$ $0.2 / 0.3$, zinc $=0.1 / 0.2$.
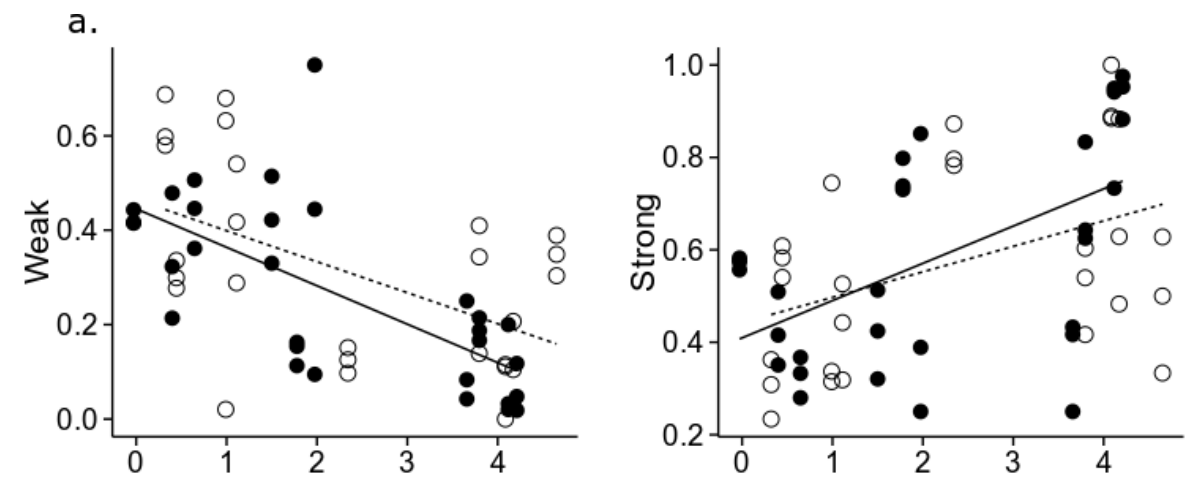

(In) Median CSCU

Year $\rightarrow 2009 \cdot \bullet \cdot 2010$
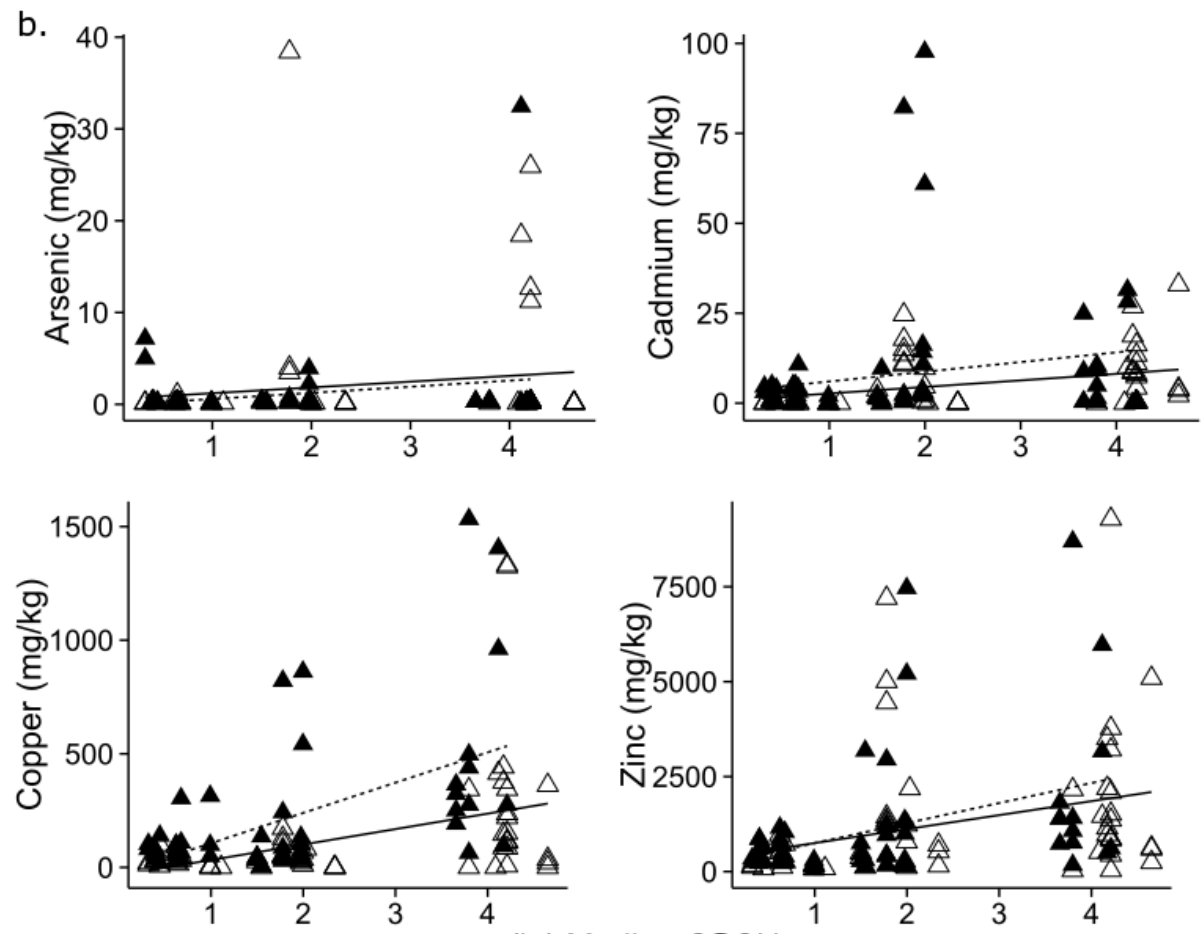

(In) Median CSCU

Drift category $\triangle$ Strong $-\star$ Weak 
Figure 6. Metal exposure values (EV) based on availability of metal-contaminated aquatic invertebrates varied with sediment CSCU. With the exception of one reference site, our moderately contaminated sites had some of the highest exposure values for cadmium, copper, and zinc due to the effect of higher aquatic invertebrate densities and moderate metals concentrations. Arsenic EV's did not exhibit a pattern across the range of sediment contamination levels.
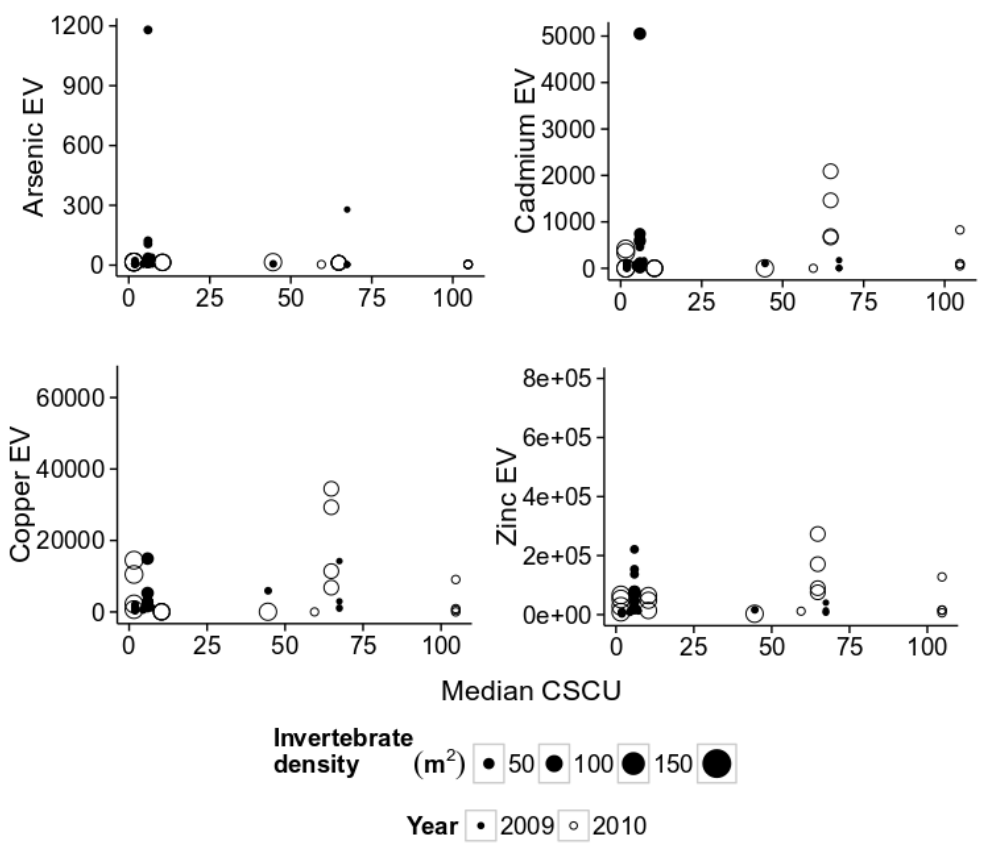

Figure 7. Metals concentrations in fish exhibit a similar pattern as invertebrate exposure values, with the highest fish metals concentrations observed at moderately contaminated sites (median CSCU $=65$ ).
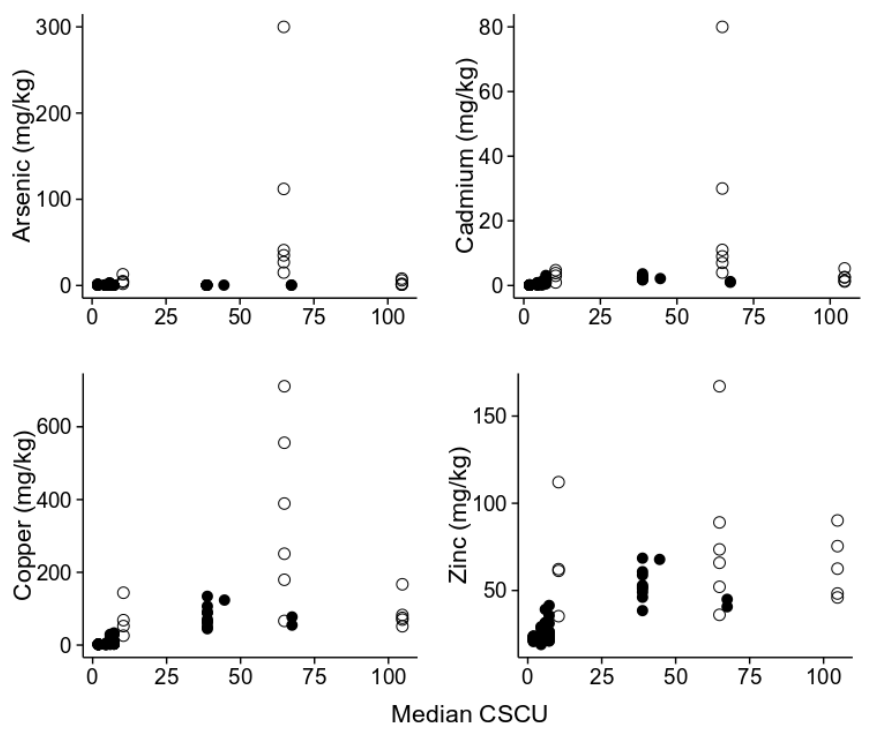

Year $\cdot 2009 \circ 2010$ 